\title{
Paradox vymístění: príspěvek k posttotalitní reflexi vztahů se sudetskými Němci a polsko-židovských vztahů
}

\author{
Marcel Tomášek
}

Židovská menšina v Polsku, která, obdobně jako německá menšina v českém pohraničí, byla často lokální většinou či paritou, zůstala $\mathrm{v}$ důsledku událostí války a dění po ní bezprostředně následujícího pouhým vzpomínkovým obrazem. Obrazem rychle zastřeným do té doby jen těžko představitelným, přesto rychlým, nástupem komunismu. Realita každodenního života těchto menšin a jejich soužití s většinovým živlem, tak, jak existovaly v předválečném kontextu, byly v období vlády komunistického režimu zcela změněny a menšina jako taková se stala primárně hrozbou. I tehdy, když př́slušníci menšiny nebyli fyzicky př́tomni, reprezentovala, a mnohdy stále reprezentuje, v obecném povědomí daná menšina klíčovou hrozbu, která dlouhodobě přispívala k upevnění totalitního režimu. Tento proces nazývám „paradoxem vymístění".

Výzkum tohoto paradoxu má pochopitelně značný význam pro analýzu mechanizmů charakterizujících fungování totalitního režimu. Navíc v situaci, v níž otázka vysídlení představuje jedno $\mathrm{z}$ nejdůležitějších dlouhodobých témat $\mathrm{v}$ současné české politice a v níž v rámci populistické hry o voliče dochází k oživování komunistické mentality, je aktuální podívat se na problémy spojené s reflexí traumatické minulosti1 u našeho polského souseda. Polská zkušenost by nám mohla pomoci porozumět problémům vážícím se na naši reflexi vymístění německé menšiny.

Účelem textu je představit společenskou reflexi česko-sudetoněmeckých vztahů a polsko-židovských vztahů a genezi této reflexe (jak byla iniciována konkrétními klíčovými texty J. T. Grosse v roce 2000 a Danubiuse - Jana Mlynárika - v roce 1978), a to jak z hlediska její manifestace $v$ širším veřejném povědomí (mediální obraz), tak i v úžeji akademicky vymezeném chápání, a průběh této reflexe nahlédnout sociologicky. Konceptem, který se analyticky nabízí pro tento účel, je kolektivní trauma, umožňující osvětlit specifickou dynamiku této reflexe $\mathrm{v}$ obou sledovaných př́padech. Vztahům česko-sudetoněmeckým je vzhledem $\mathrm{k}$ jejich vyhrocenosti a dlouhodobému přetrvávání $\mathrm{v}$ centru aktuálního politického dění věnováno více prostoru. Slouží zde za př́íklad převládající neschopnosti otevřené reflexe vztahů $\mathrm{s}$ vymístěnou menšinou a neschopnosti vypořádání se s kolektivním traumatem způsobeného násilí. Př́klad polsko-židovských vztahů v tomto kontextu slouží jako ilustrace důsledků „odkrývající“ reflexe a procesu akceptace návratu vymístěné menšiny, i když mnohdy již jen v symbolickém rozměru.

Sociálni studia. Fakulta sociálních studií Masarykovy univerzity v Brně, 2/2004. S. 129-154.

ISSN 1214-813X. 
V roce 2000 vydalo polské nakladatelství Pogranicze knihu profesora Newyorské university Jana Tomáše Grosse nazvanou Sousedi. Historie záhuby židovského městečka (anglický název Neighbours: The Destruction of the Jewish Community in Jedwabne, Poland, 2001, polsky jako Sasiedzi. Historia zagłady żydowskiego miasteczka, Pogranicze 2000). Kniha na sto stranách formou historického eseje načrtla zánik židovské populace ve východopolském městečku, ke kterému došlo na samém počátku nacistické okupace. ${ }^{2}$

Poburưjícím odhalením, které vyvolalo celonárodní kontroverzi zaznamenávanou v následujících několika měsících každodenně na prvních stránkách polských deníků a týdeníků, byla skutečnost, že v městečku Jedwabne došlo za organizační účasti místní městské samosprávy k úplnému vyvraždění židovských obyvatel jejich polskými sousedy v momentu, kdy několik málo př́slušníků německých represivních složek, kteří městečko navštívili, nebylo $\mathrm{s}$ to likvidaci židovských obyvatel v tak obludném rozsahu realizovat.

\section{Vymístění polského židovského obyvatelstva: historický kontext}

\section{Sovětská okupace a židovská menšina}

V souladu s klauzulemi srpnového paktu uzavřeného mezi nacistickým Německem a Sovětským svazem byla v druhé polovině záři 1939 Sovětským svazem okupována východní část Polska . K této okupaci na východě současného Polska často docházelo tak, že německá vojska se po několika dnech stáhla z již okupovaných oblastí, aby tyto byly obsazeny Rudou armádou. V momentech bezprostředního nebezpečí nacistické okupace byla sovětská vojska často vítána židovskou populací, což bylo Poláky vnímáno jako jednoznačná zrada. V některých oblastech, kde antisemitské útoky před válkou byly obzvláště časté ${ }^{3}$ a kde působilo rozvinuté komunistické hnutí se silným židovským prvkem, došlo i k útokům na polská vojska a další polské ozbrojené složky, inspirovaným a organizačně zajištěným sovětskou agenturní sítí. Tyto incidenty se projevily rozsáhleji v oblasti Grodna a okolí. Zároveň je však nutné říci, že $\mathrm{v}$ rámci polské armády se bojových akcí v zááí 1939 zúčastnilo asi 100 tisíc vojáků židovského původu. Většina z nich nepřežila válku, ti, co nezahynuli během záŕijové kampaně a dostali se do zajetí, byli později zavražděni. Odhaduje se, že mezi tisíci polských důstojníků zavražděných NKVD v sovětském zajetí po začátku války bylo asi 400 židovského původu.

Př́íchod sovětské moci znamenal zásadní zvrat v dosavadní organizaci života $\mathrm{v}$ těchto periferních oblastech polské „II Rzeczypospolitej“, privilegované postavení polského živlu bylo zvráceno během několika málo dní ve prospěch židovského, ukrajinského a běloruského elementu. Adepti na místa v nově utvořené administrativě, pokud nebyli polskými komunisty, pocházeli převážně z těchto národnostních menšin (jestliže o nich můžeme mluvit na daném teritoriu jako o menšinách, když byly často stejně početné jako polská „většina“). Tímto se skončil monopol Poláků na kontrolu a obsazování městských, municipálních a dalších orgánů. Toto, vedle zespolečenšt'ující reformy hospodářského života iniciované a organizované sovětskými okupanty, bývá chápáno jako důkaz antipolskosti židovské menšiny a potvrzení př́klonu ke komunismu u členů židovského společenství. Obyvatelstvo Sověty nově okupovaných teritorií bylo podřizeno rozsáhlým represím. Odhaduje se, že z těchto oblastí bylo vysídleno 
na Sibiř nebo jinak postiženo 400 až 700 tisíc obyvatel. Tyto represe jsou někdy označovány za holocaust Poláků prováděný sovětskými bezpečnostními orgány a jejich místními židovskými pomocníky, paradoxem ovšem je, že až 30 procent z těchto postižených bylo židovského původu. V sovětské okupační zóně se shromáždilo velké množství židovských uprchlíků z centrálního Polska. V důsledku špatných existenčních podmínek na tomto teritoriu, které byly dány sovětským způsobem reorganizace společnosti, se mnoho z těchto uprchlíků rozhodlo k návratu do původních domovů v Němci okupované části Polska. Takovéto pokusy o návrat ve velké části př́ípadů skončily deportací na Sibiř.

Útok na Sovětský svaz v červnu 1941 znamenal pro židovské obyvatelstvo ve východní části předválečného Polska pohromu. Nepřehledná situace, která zavládla v prvních dnech německého útoku, vytvořila prostor pro vlnu spontánních pogromů. Vesnické obyvatelstvo, at' již polského nebo ukrajinského původu, iniciovalo tyto pogromy bezprostředně, tak jak to bylo obvyklé v historicky bouřlivých situacích vyznačujících se dočasným chaosem a dezintegrací společenských kontrolních mechanizmů. Jejich první vlna proběhla ještě před tím, než nad danými teritorii převzali úplnou vojenskou kontrolu Němci. Zdá se, že další vlna pogromů (začátek července 1941), jež následovala, probíhala již za účasti německých speciálních komand určených pro východní teritoria s úkolem iniciovat a provokovat protižidovské akce s využitím místní zakořeněné antipatie vůči židovskému obyvatelstvu. Právě o míře účasti členů takovéhoto komanda $\mathrm{v}$ iniciování a průběhu červencových událostí v Jedwabnem byl veden výše uvedený spor. Obvyklá vysvětlení chování mnoha Poláků v červenci 1941 z tábora obránců „polské cti““ směřují k tvrzení, že ze strany Poláků se jednalo o zaslouženou pomstu za antipolské chování Židů za sovětské okupace, za jejich participaci v sovětské administrativě a pomoc sovětskému represivnímu aparátu.

\section{Vznik PLR a Židé}

Tyto nálady spojující sovětský režim s židovskou populací byly během války živeny nacistickou propagandou. Takto povzbuzované národnostní rozpory byly tak silné, že - specielně ve východních oblastech Polska - antifašistický odboj zůstal rozdělen. Židovští utečenci z vyvražd’ovaných ghet nemohli vstupovat do polských partyzánských oddílů „Armii Krajowej“ a dalších formací spojených s polskou exilovou vládou a obvykle byli nuceni se připojit k sovětským partyzánům, kteří se snažili na východních teritoriích uplatnit sovětský vliv a často se střetávali a konfrontovali právě s oddíly „Armii Krajowej“.

Sovětský svaz a polská exilová vláda $\mathrm{v}$ Londýně se dostávaly do častých rozporů a s koncem války byly vzájemné vztahy v podstatě přerušeny (první polský vojenský kontingent, který se vytvořil v Sovětském svazu, byl přenesen na Blízký východ, a tím byl vytvořen prostor pro vznik Sověty a komunisty jednoznačně dominované vojenské formace Berlinga). Sovětská vláda neuznávala jurisdikci polské exilové vlády, bojové podzemní formace v Polsku, s touto vládou asociované, naopak považovala za nepřátelské, včetně domácí politické reprezentace londýnské vlády. V srpnu 1944 zastavila Sovětská armáda svoji ofenzívu na předměstích Varšavy, a nechala Němce přes několik měsícủ pacifikovat vzniklé povstání (ke kterému sama vyzývala), zabraňujíc efektivním dodávkám výzbroje povstalcům západním letectvem. Následně, konflikt, který doprovázel „osvobozeni““, tedy spíše vojenské obsazení Polska, jednoznačně definoval pozici komunistické vlády. 
Židé, kteří př̌žili válku, stáli před celou řadou dilemat. Ukázalo se, že návrat do polské společnosti nebude jednoduchý - z celé předválečné židovské populace v Polsku (3 miliony 400 tisíc) uniklo holocaustu asi 340 tisíc osob. Pro zachráněné jednotlivce bylo snadné hledat bezpečí a uplatnění v řadách nového komunistického aparátu. Roli v tom sehrál i motiv osobní pomsty za válečná př́ikoří. Většina Židů, která se zachránila útěkem, utekla na východ. To nevyhnutelně vedlo ke kontaktu s utvářejícími se strukturami nového komunistického režimu. Často se uvádí, že v represivním aparátu, který byl bezprostředně po válce použit proti německé menšině, Židé dominovali. Hlavním objektem represí se záhy stali lidé zapojení do podzemních struktur. Obzvláště na východě Polska docházelo k regulérním ozbrojeným srážkám. Pro židovskou inteligenci, která př̌žila válku, byla účast ve strukturách komunistické vlády jedinečnou šancí, jak se plnohodnotně uplatnit a překonat národnostně daná omezení, která charakterizovala život $\mathrm{v}$ předválečném Polsku. Přesto je nutno podotknout, že značná část př́slušníků židovské menšiny, kteří se zachránili, z Polska emigrovala. Došlo k tomu v důsledku těžké pozice této menšiny v poválečné době. Na jedné straně byli přeživší Židé napadáni a zabíjení ze zištných důvodů - jakmile se přihlásili o své vlastnictví zabrané za války polskými spoluobčany -, na straně druhé byl důvodem k útokům antisemitismus aktuálně spjatý s opozicí vi̊či komunistickému režimu. Celkově se odhaduje, že po válce byly zavražděny asi dva tisíce lidí židovského původu. Takovéto pozadí mělo násilí a pogromy, které zachvátily některé oblasti země v roce 1946 (Řešov, Krakov, Kielce, Podkarpatí). Bezprostředně po pogromu v Kielcach z Polska uteklo asi 200 tisíc lidí židovského původu. Problematický politický kontext podtrhuje fakt, že tehdejší polská katolická církev odmítla proti tomuto násilí vystoupit. Pro katolickou církev ospravedlňoval boj polského společenství proti komunismu i pogromy a násilí na zbylých členech židovského společenství. ${ }^{4}$ Př́slušníci komunistického aparátu židovského původu byli z pochopitelných důvodů sekularizováni a jednoznačně směřovali k asimilaci. Těmito poválečnými událostmi došlo v Polsku k vymístění židovského živlu jako signifikantního distinktivního společenství.

\section{Vymístěné židovské společenství a Polská lidová republika}

Navzdory faktickému vymístění př̌živší části židovské menšiny - sehrála v novém totalitním režimu problematika této menšiny kritickou roli a došlo v ní ke značně specifickým posunům. Začátky komunistického „lidového“ režimu charakterizovala v nejširších vrstvách obyvatelstva představa Židů jako těch, kteří ve svém zájmu vládnou Polsku. ${ }^{5}$ Prosadil se takto stereotyp ,židokomuny“ (,, Polsku je vláda žido-sovětská“), ${ }^{6}$ jehož reminiscence se v polském společenském kontextu objevují dodnes. Přestože tento stereotyp byl prvotně jednoznačně spojen s opozicí vůči novému „lidovému“ režimu, anti-židovské nálady postupně zasáhly i komunistický stranický aparát a jejich šiření zesílilo v roce $1956 .{ }^{7} \mathrm{~V}$ souvislosti se změnami politických poměru (nástup Gomulki) začalo docházet k výraznému posunu ve vztahu k soudruhům židovského původu ve stranickém aparátu. ${ }^{8}$

Kulminačním momentem v tomto procesu se staly události let 1967 a 1968. „Židovský problém" posloužil v této době ke stabilizaci a hibernaci komunistického režimu. (Ačkoli po holocaustu a poválečném exodu přeživších Židů již jen těžko můžeme v kontextu komunistického režimu mluvit o židovském společenství.) 
Počátky antisemitské „náhonky“, která posloužila v PLR k vypořádání se s událostmi roku 1968, i v Polsku bouřlivými, sahají do roku 1967. V souvislosti s izraelsko-arabským konfliktem došlo na „oddělování zrna od plev“. Polská lidová republika zaujala ke konfliktu totožné stanovisko jako ostatní členské státy komunistického tábora - jednoznačně se postavila na arabskou stranu. Tato oficiální pozice vedla ke kritické odezvě mezi inteligencí a pracovníky administrativního aparátu židovského původu. Tato většinou neformální stanoviska zavdala příčinu k prověrkám a čistkám prováděným především v médiích. ${ }^{9}$ Pracovníci židovského původu byli káráni a přeřazováni na méně důležité pozice.

Mnohem intenzivnější impetus získala tato kampaň s vyhrocením situace na přelomu února a března 1968. V souvislosti s protesty proti stažení hry Dziady Adama Mickiewicze z nabídky Národního divadla a vyloučením některých studentů podílejících se na těchto protestech (Adama Michnika, Henryka Szlajfera) z univerzity došlo k patové situaci. Pokojné shromáždění studentů za navrácení studentských práv dvěma jejich kolegům, kterým byla tato práva pozastavena a jimž hrozilo vyloučení, bylo rozehnáno policií a Občanskou milicí (obdoba Lidové milice v ČSSR). Tato šokující událost odstartovala nástup studentského hnutí ve Varšavě a v dalších akademických centrech. Šírící se studentské nepokoje mnohdy přerostly v pouliční srážky nejen univerzitní mládeže s policií. Situace byla „vyřešena“ svalením viny za nepokoje a společenské rozruchy na ,zlatou maloburžoazní a inteligentskou mládež židovských rodičů‘. Komunistický režim takto využil poválečných antipatií Poláků vůči Židům. Tento původní motiv se během několika málo dnů rozvinul v jednoznačnou a př́močarou antisemitskou kampaň. Absurditu této situace v daném společenském kontextu násobilo využití celé škály prostředků propagandistického aparátu komunistického režimu - od dezinformací a propagandy v médiích až po svolávání mítinků ve výrobních halách. Pochopitelně právě využití propagandistických prostředků komunistického režimu vzbuzovalo určitá podezření širší veřejnosti. Dokumentární záznamy z těchto masových akcí odehrávajících se na pracovišti neukazují prŕliš entuziasmu, často spíše rozpaky. Ovšem v momentu, kdy došlo k uvolňování důležitých míst na pracovištích, v administrativě, a v médiích, kampaň získala na autentičnosti - vlna denunciací a účelových obvinění se přehnala přes mnoho společenských a zaměstnaneckých skupin. Do jisté míry podobně jako po vyhnání židovské populace do ghett či po bezprostředním vyvraždění jejích př́íslušníků v době druhé světové války došlo k zabírání židovského majetku a živností. V roce 1968 se ovšem již nejednalo bezprostředně o majetkový zisk, ale o rychlejší služební postup a posunutí se na lepší pozici v pracovní hierarchii a o lepší ekonomické postavení ex post. Tímto způsobem a za takovýchto okolností bylo donuceno odjet ze země asi 10 až 15 tisíc polských občanů (s jednorázovým a ,jednosměrným“ cestovním dokumentem bez uvedení občanství, jen s několika povolenými dolary a nejvýše dvěma zavazadly). ${ }^{10} \mathrm{~V}$ některých institucích tyto čistky nebyly jednorázovou akcí, ale měly dlouhodobější důsledky. V polské armádě probíhaly až do začátku 80 . let. V tomto období bylo z důvodu židovského původu degradováno a z polské armády vyhozeno více než 1300 osob. Některé instituce - jako například polská státní bezpečnost - v tomto období přejaly jazyk nacistické propagandy a předválečných národovců.

Předchozí řádky neměly rozhodně za cíl být přehledem polsko-židovských vztahů v soudobých dějinách, chtěly především naznačit, jak je problematika polsko-židovských vztahů propletena se vznikem komunistického režimu a jakou fundamentální roli vyvražděné a vy- 
místěné židovské společenství sehrávalo během vlády tohoto režimu. V poválečném Polsku došlo k paradoxnímu vývoji, kdy si fyzicky zmizelé společenství polských židů zachovalo roli klíčového faktoru (respektive metafaktoru) v kontextu totalitního režimu. Došlo dokonce k závažnému posunu, když antisemitismus, doprovázející konfrontaci rozsáhlých opozičních struktur s nastupujícím komunistickým režimem, byl postupem času komunistickým aparátem inkorporován a využit jako mobilizační zdroj při stabilizaci totalitního systému konfrontovaného s krizovými jevy.

\section{Společenská reflexe kruté minulosti}

Traumatické odhalení o vyvraždění židovských obyvatel Jedwabnego jejich polskými sousedy - zprostředkované polským profesorem v emigraci - odstartovalo v polské společnosti určitý proces katarze; tím, že započalo bouřlivou a hlubokou celonárodní diskusi o vztahu Poláků k Židům a o temných anti-semitských stránkách polské minulosti. Tato celonárodní diskuse a reflexe kulminovala účastí polského prezidenta a premiéra na odhalení památníku zavražděným židovským obětem na místě stodoly, v níž byli židovští občané svými polskými sousedy upáleni. V průběhu několikaleté diskusní kampaně (od dubna 2000 ${ }^{11}$ byly rozsáhle prezentovány i antisemitské a národovecké pozice a sama katolická církev - v Polsku klíčová instituce - nereflektovala v úplnosti závažnost odhalení. ${ }^{12}$ Prof. Tomáš Strzembosz, historik zaměřující se na polská hnutí odporu, tedy především na činnost „Armii Krajowej“ v době Druhé světové války, se pokusil interpretovat vraždění v Jedwabnem jako represivní akci gestapa (navýšil odhadovaný počet jeho př́islušníků), která využila několik Poláků ze společenského okraje ${ }^{13}$, motivovaných snahou „odplaty za vinu Židů na pronásledování Poláků za předešlé sovětské okupace“. ${ }^{14}$ Navzdory vyhraněným pozicím $\mathrm{v}$ tomto kontroverzním případě přineslo oficiální vyšetřování Institutu národní paměti (obdoba našeho Úřadu pro vyšetřování zločinů komunizmu) konkrétní závěry prokazující neúčast německých ozbrojených složek v likvidaci několika stovek obyvatel Jedwabnego a potvrdilo svědectví prezentovaná $\mathrm{v}$ knize. ${ }^{15}$

V diskuzi se z historického pohledu vyhranily dvě pozice, reprezentované J. T. Grossem a T. Strzemboszem. Pozice T. Strzembosza představovala v dosavadní polské historiografii, domácí i emigrantské, klasický př́istup ke konkrétním válečným situacím vrhajícím špatné světlo na př́slušníky polského národa. Podle této interpretace se vždy jednalo o lidi z okraje polské společnosti, lidi, kteř́ nepomohli z obavy z trestu smrti, nebo se nejednalo o Poláky, ale např́klad o Ukrajince. V prrípadě Jedwabnego byla tato obvyklá vysvětlení poměrně jednoznačně vyvrácena: 1) nebylo možné ŕíci, že se jednalo o lidi z okraje společnosti - v akci se angažovalo celé lokální společenství, zúčastnili se jí zcela normální lidé - od sedláka až po starostu, nešlo o lupiče ani vyděrače ukrývajících se Židů; 2) neplatí zde ani teze o obavě $z$ trestu smrti za pomoc, nešlo o pomoc ale o účast na pogromu; 3) vinu nelze svalit ani na jiná etnika; jak na Ukrajince, často prezentované v podobných kontextech (vrazi, strážci v koncentračních táborech), tak na jiné národnosti - Litevce, Němce (J. T. Gross v rozhovoru pro $L N 19 / 2002$, s. 5). V př́ípadě Jedwabnego bylo velice těžké se reflexi tragické události vyhnout nebo ji odmítnout obvyklými způsoby. Lidé tento drastický moment v polsko-židovských vztazích museli reflektovat a v důsledku rozsáhlé a extrémně vyhrocené diskuse - která 
ze strany „negativistů“ přinášela všechny obvyklé a stereotypní argumenty (hlavně argument ,židokomunistický“) ospravedlňující násilí na židovském společenství v celém úseku soudobých polských dějin - konfrontovat staré argumenty ve zcela novém světle.

Přestože tato vyhrocená diskuse a samotné otevření památníku ${ }^{16}$ bezprostředně předcházelo volbám konaným v záŕí 2001, které rozhodovaly o klíčové výměně pravicové koalice postkomunistickou sociálně demokratickou levicí, kauza Jedwabnego se nestala předmětem předvolebních kampaní jednotlivých stran. Otázky spojené s nedávno exponovanými př́íklady polské represe židovského živlu a jejich společenské reflexe se nedostaly do centra předvolebního politického dění a nestaly se bojovým nástrojem v předvolební kampani.

\section{Vymístění československých Němců: historický kontext}

\section{Odsun a zdroje kontinuity totalitního režimu v Československu}

V roce 1978 publikoval slovenský historik Jan Mlynárik pod pseudonymem Danubius v časopise Svédectví studii pod názvem „Tézy o vysídlení československých Nemcov“ (57/ 1978, s. 105-122). Příspěvek působil téměř jako blesk z čistého nebe: představil ve zcela novém historickém kontextu význam odsunu sudetských Němců ${ }^{17}$ a jeho fatální důsledky pro další vývoj Československa a rozproudil žhavou, často velice úpornou, diskusi v řadách disentu, jejíž výsledky se bezprostředně odrazily i v prvotních krocích nové politické reprezentace po roce 1989. Mlynárikovy „Tézy“ byly v tomto kritickém období (formování Charty 77 z velice různorodých ideových zdrojů a skupinových základů) konfrontovány některými klíčovými ex-komunistickými historiky (M. Hubl, J. Křen) a kriticky komentovány a rozvíjeny dalšími účastníky diskuse (L. Hejdánek, E. Kohák, P. Příhoda, J. W. Brugel, L. Kohout, R. Luža, Z. Mlynář, T. Brot, J. Doležal, M. Otáhal, P. Pithart, J. Opat, V. Vrabec, V. Kural, V. Prečan). ${ }^{18}$

„Tézy o vysídlení československých Nemcov“ dodnes reprezentují klíčový př́íspěvek v nahlížení na problematiku odsunu a jeho významu pro instalaci a udržování totalitního režimu v Československu. Předestřené ,tézy“ přitom ani 15 let po dekompozici tohoto totalitního režimu neztělesňují stěžejní pozici ve vypořádávání se s tragickou minulostí odsunu; a to přesto, že k dosažení takové pozice směřovaly.

I po téměř 30 letech představují „Tézy“ z hlediska odsunu kritické problémy pro další vývoj Československa v úplnosti, která nevyžadovala výraznější revize ani po roce 1989. Ve zkratce je lze rekapitulovat následovně: ${ }^{19}$

1) V ,paušálním odsouzení československých Němců ne podle míry viny, ale podle př́slušnosti k národnosti“ došlo k aplikaci prvků „orientálně-asiatských stalinských transferů“ (Danubius-Mlynárik 1990: 63-64), 2), které se nakonec prosadily v důsledku moskevských jednání prezidenta E. Beneše s J. Stalinem (prosinec 1943). Sověti vycítili až iracionální a nestátnickou utkvělost Benešovy snahy zbavit se německého živlu v poválečném Československu a tuto př́ležitost mnohonásobně využili: a) Beneš a jeho emigrantská vláda byli zavázáni Sovětskému svazu za kategorickou podporu ve věci totálního transferu československých Němců (této podpory totálního odsunu a s ním souvisejícího nárůstu sovětského vlivu ve vztahu k československé vládě bylo použito k vynucení jednoznačného souhlasu 
západních mocností s vlastním odsunem); b) v jednoznačném souladu se zájmy komunistů a Sovětů se německý majetek měl „stát základem všeobecného znárodnění a socializace ČSR, strukturální sociální přeměny ČSR“; c) Sovětský svaz si takto vytvořil legální předpoklady pro využití možnosti násilných migrací $\mathrm{k}$ vytvoření je doprovázejícího stavu bezpráví a „civilizačního vytržení“, optimálního pro uplatnění sovětské mocenské kontroly nad československým územím (Danubius-Mlynárik 1990: 72-73). ${ }^{20}$

3) Prezident E. Beneš a československá vláda při dožadování se mezinárodních práv důsledně vycházeli z kontinuity Československa - z jeho územní celistvosti a vnitřní integrity. To se plně týkalo i všeho obyvatelstva na území Československa v předmnichovských hranicích a znamenalo zneuznání všech právních úkonů okupanta - tedy i přiznání říšského občanství př́islušníkům německé menšiny na obsazených územích; výjimky z tohoto principu nebyly možné, jestliže měla být koncepce odzískání mezinárodních práv a statutu ČSR funkční (Danubius-Mlynárik 1990: 59-60). ${ }^{21}$

4) Hnutí a aktivity K. Henlaina a K. H. Franka „nebyly organickým důsledkem vývoje, či jakýmsi ,vyústěním‘ toku této civilizace na československém území, ale momentální historickou anomálii““; ,přijetí opačné teze znamená, že německé dějiny vyústily v III. říši a v A. Hitlerovi a že celý předcházející vývoj německých kmenů a pozdějšího národa byl jenom př́ípravou $\mathrm{k}$ tomuto vítězství“. Odsunem tedy byla eliminována vlastní československá populace historicko-geograficky bezprostředně svázaná s tímto prostorem (Danubius-Mlynárik 1990: 61).

5) Nacionálně socialistická demagogie Henleina a jeho strany by se neuplatnila nebýt hluboké ekonomické krize. Krize se $\mathrm{v}$ pohraničí projevila ještě silněji než v jiných oblastech Československa, včetně masových hnutí a stávek, které československé orgány vedly k použití krajních prostředků (střelba do demonstrujících a stávkujících v Duchcově, Frývaldově a jinde) (Danubius-Mlynárik 1990: 61-62).

6) Meziválečné československé vlády mají svoji část viny na přehlížení sociálních a národnostních požadavků československých Němců, respektive na nabídce jejich řešení až v momentu bezprostřední krize (předložení takovýchto nabídek o několik let dříve mohlo výrazně omezit nárůst iredentistického hnutí a redukovat jeho masový charakter) (DanubiusMlynárik 1990: 62).

7) „Totalitní režim nacistického Německa a okupace českých území přivedly mnohé čsl. Němce ke zločineckému aktivismu, což se projevilo nejvíce ve vyhnání více než 100000 Čechů z pohraničí (v letech 1938-1939), ve službě okupantovi na českém území stejně jako ve službě v policii a armádě. To všechno byly akty zločinnosti, které měly být trestány individuálně; jednotlivci, uskutečňující násilí, měli být postaveni podle míry své viny před soud národa, proti kterému se tak vážně provinili. Avšak tento pojem individuální viny byl zastřen ,kolektivní vinou' všech čsl. Němců. Dnes už přece víme, co dokáže totalitní režim udělat $\mathrm{s}$ národem (a především $\mathrm{v}$ době války a teroru), jak ho dotáhne mnohými prostředky $\mathrm{k}$ souhlasu se svojí politikou a jak znásilní národ“ (Danubius-Mlynárik 1990: 63). Přesto podle Danubiuse-Mlynárika „sociologický vzorec aktivizmu v totalitním státě sotva přesahuje 10-15\% obyvatelstva; ostatní se ,vezou' formálním schvalováním politiky režimu (účast ve volbách a jiných obecných akcích režimu)“, a tedy i při nadsazení celkového počtu ,aktivistická nacistická a fašistická skupina mezi čsl. Němci nepřesahovala 300 000-500 000 osob“ (Danubius-Mlynárik 1990: 63). 
8) „Samotný transfer vycházel z hlubiny iracionální pomsty“ (Danubius-Mlynárik 1990: 64) a primárně zahrnoval rozsáhlé nesrovnalosti. Mezi Danubiusem-Mlynárikem zmíněnými „nesrovnalostmi“ vyniká především skutečnost, že mnohým aktivním kolaborantům se povedlo přejít do státního aparátu nové moci a podílet se na násilí poválečného období. ${ }^{22}$ Podobně i ti nacističtí provinilci a zločinci, kteří byli individuálně odsouzeni českými soudy za svoji činnost za okupace $\mathrm{k}$ dlouholetým trestům, byli mnohdy po krátké době propuštěni $\mathrm{z}$ důvodu odsunu. ${ }^{23}$ Transfer tedy pomohl skutečným zločincům a trestal nevinné (1990: 64). ${ }^{24}$ V Benešově rozhodování vedeném ,iracionálním pocitem pomsty za rozbití čsl. státu“ (podle Danubiuse-Mlynárika souvisel jeho pád více než s československými Němci s rozpadem versailleského systému a novými a novými ústupky spojeneckých západních mocností hitlerovskému Německu) sehrál svoji roli i postoj širšího obyvatelstva, které ale bylo fakticky motivované svojí vlastní nečinností, př́padně kolaborací, v době války, již chtělo napravit „ex-post ,hrdinstvím“ na bezbranných“, což bylo „pro národ kompenzací, ventilem oportunizmu a zlého svědomí“ (Danubius-Mlynárik 1990: 71).

Jediným, co je podle Danubiuse-Mlynárika možné uvést na obranu prezidenta Beneše, je skutečnost, že Beneš ,jako dítě liberalizmu a parlamentarizmu“ nebyl schopný pochopit a konfrontovat „manipulace totalitních režimů s velkými skupinami lidí a rozhodnutí a činy celých těchto sociálních skupin či menšin (čsl. Němců) považoval a vydával za výsledek myšlení a konání svobodných lidských bytosti'“ (1990: 71). Navzdory svým diplomatickým zkušenostem a dovednostem z působení na mezinárodní politické scéně ve 20. a 30. letech nebyl prezident Beneš schopen pochopit Stalina a motivace stojící za jeho rozhodnutími (Danubius-Mlynárik 1990: 71-72).

Takto mohou být tedy ve zkratce představeny základní teze - vztahující se k tématu vypořádání se s odsunem - klíčového historického př́ispěvku Danubiuse - Jana Mlynárika.

Obvyklou reakcí na tyto teze $\mathrm{v}$ historických diskusích před i po roce 1989 je otázka, jaký alternativní př́stup k československým Němcům mohl být realizován v situaci dané tehdejšími společenskými náladami a obecněji poválečnými poměry, následovaná okamžitou odpovědí poukazující na snílkovství a ahistoričnost alternativ. Opomíjeným faktem v těchto diskusích zůstává, že, jak poukázal již Danubius-Mlynárik (1990: 65) ve svých „Tézach“, $\mathrm{k}$ humanističtější alternativě $\mathrm{v}$ Československém poválečném kontextu došlo. Případ mad'arské menšiny, jenž měl být vzhledem k iredentismu Mad’arů (prričlenění třetiny Slovenska k Mad’arsku) ,řešen“ v souladu s tzv. „Košickým vládním programem“ a projektem vysídlení neslovanského obyvatelstva totožně jako v př́padě Němců odsunem, nakonec vyústil v omezenou reciproční výměnu obyvatelstva (vedle vyhnání několika tisíc aktivních iredentistů) a pozdější účast v znovuosídlování českého pohraničí.

\section{Návrat k vymístěnému společenství?}

Podobně jako po uveřejnění „Téz“" v disidentských kruzích a v časopise Svědectví v roce $1978,{ }^{25}$ vyvolalo náhlou a polarizovanou diskusi o odsunu prohlášení budoucího prezidenta Václava Havla 23. prosince 1989. Havel se v něm vyjádřil o povinnosti omluvit se za odsun jako „akt tvrdého zbavení několika miliónů lidí jejich domova“ v reakci na prohlášení bavorského premiéra Maxe Stoibera vítajícího změny, k nimž došlo v Československu, a vyslovu- 
jícího naději, že dojde k brzkému porozumění mezi Čechy a sudetskými Němci. Prohlášení Václava Havla výrazně akcentovalo př́ístup k odsunu vygenerovaný diskusemi o „Tézach“ v rámci Charty $77^{26}$ na přelomu 70 . a 80 . let.

Takto bylo pro českou nejširší veřejnost bezprostředně a pravděpodobně i značně neočekávaně znovu objeveno "zapomenuté“ a komunistickým režimem tabuizované téma. ${ }^{27}$ Poněkud paradoxně narazili mnozí z československých občanů na téma odsunu poprvé v životě (např́klad i V. Klaus, jak sám přiznal), ačkoli „nebezpečí sudetoněmeckých revanšistů v NSR" patřilo k jednomu z legitimizačních prostředků československého komunistického režimu s nejuniverzálnějším potenciálem. Bylo pro československé občany denním chlebem tak zapsaným do podvědomí, že jenom nemnozí si kladli otázku, kde se „sudetoněmečtí revanšisté " v NSR vzali, a pamětníci, kteří si tuto otázku klást nemuseli, o této životní kapitole spíše mlčeli. Tento náhlý začátek diskuse vyvolal ovšem rozsáhlou reakci široké veřejnosti. Přestože postoj Václava Havla přinesl rozsáhle negativní reakce, zároveň byl tímto náhlým uvedením tabuizovaného tématu vytvořen prostor pro, v řadách československé veřejnosti doposavad nepř́liš strukturovanou, diskusi kriticky namířenou proti odsunu. $\mathrm{V}$ praxi se tento charakter veřejné debaty odrazil na počátečním vývoji př́istupů $\mathrm{k}$ tématice odsunu v prostoru mediální scény.

P. Př́hoda a P. Pithart ve svém výběru př́ispěvků $\mathrm{k}$ „odsunutým dějinám“ $\mathrm{z}$ roku 1998 charakterizují situaci v periodickém tisku v úvodní fázi debaty o odsunu rozdělením na levicově orientované deníky a časopisy, od počátku se jednoznačně ztotožňující s odsunem, a pravicový tisk, který byl z počátku nevyhraněný a $\mathrm{v}$ němž se právě vytvořil prostor pro předem nestrukturovanou výměnu názorů. Tento charakter pravicového tisku byl ještě posílen skutečností, že periodika $v$ této době byla rozsáhle otevřena prríspěvkům z vnějšku, včetně dopisů čtenářù. Jednoznačně kriticky ve věci odsunu se profiloval Český deník (pozdější Český týdenik), z hlavních deníků byla více kritickým př́íspěvkům otevřena Mladá fronta Dnes a Denní Telegraf (Př́hoda a Pithart 1998: 70). Tento volný prostor se ovšem postupně zúžil (např́klad zánikem Českého deniku/týdeníku).

Na úrovni knižní produkce prostor pro diskusi otevřela především klíčová publikace v roce 1990 - obsahující záznam bouřlivé disidentské výměny př́spěvků z konce 70. let, jak byly zaznamenány ve Svědectví a v dalších emigrantských periodicích (Češi, Němci, odsun; editováno B. Černým, J. Křenem, V. Kuralem a M. Otáhalem). Publikace pochopitelně na jednom z prvních míst zahrnula „Tézy o vysídlení československých Nemcov“ Danubiuse-Jana Mlynárika. Zásadní byla také kratší práce J. Kučery Odsun nebo vyhnání? z roku 1991. Další odhalující prací, již propracovaněji monografického charakteru, byl Odsun Němců z Československa T. Staňka z roku 1991. Zdá se, že tato bezprostředně porevoluční knižní produkce přispěla $\mathrm{k}$ tomu, že v periodicích se mohla $\mathrm{v}$ tomto vstupním období šířeji uchytit pozice odsuzující odsun a nově poukazující na jeho důsledky. Tato otevřená fáze historické reflexe byla nakonec v politické sféře doprovázena bouřlivým děním provázejícím rozpad Československa a zároveň i pokusem nového českého vedení reflektovat na některé připomínky ze sudetoněmecké strany (zrízení prrípravné komise, jejíž úředníci měli být zmocněni k sondážním jednáním - činnost komise byla ovšem - po vystoupení Franze Neubauera při př́ležitosti svatodušních svátků v roce 1993 - zastavena, a tak vůbec nedošlo $\mathrm{k}$ jejímu uplatnění [Př́íhoda 1998: 44]). Ovšem nový, národněji orientovaný, veřejný diskurz, který převládl po rozpadu 
Československa, ${ }^{28}$ a psychologický efekt „,malosti“ spojený s rozpadem byly spolu s pevnější a populističtěji danou strukturací mediální sféry (nástup TV Nova) faktorem přispívajícím k uzavření prostoru pro akcentovaní kritického hodnocení odsunu.

Nekomunikace se sudetskými Němci a s ní spojené opakované výzvy k přehodnocení odsunu vedly k rozčilení mezi českou veřejností. Byla zde otázka jednání vlády se sudetskými Němci a dilema politické poptávky. Debata v médiích se začala soustředit kolem tvrzení, že odsun souvisel s individuálními excesy, ovšem zároveň byl pouhou odpovědí na předešlé činy Němců a fakticky byl racionálním naplněním na Čechoslováky uvaleného rozhodnutí vítězných velmocí. Dne 17. února 1995 vystoupil prezident Václav Havel v pražském Karolinu s projevem, který této politické poptávce více než dostál. Prezident se distancoval od svých predešlých stanovisek vycházejících z kritického pojetí odsunu, tak jak bylo diskutováno $\mathrm{v}$ disentu, a akcentoval elementy mající svůj původ v pojetí převládajícím v období komunistického režimu. ${ }^{29}$ Klíčovým politickým krokem v Havlově projevu bylo přistoupení na princip „tlusté čáry“ a vyjádření explicitní politické podpory tomuto principu, ${ }^{30}$ která byla v jeho projevu bezprostředně politicky aplikována odmítnutím jakékoli „materiální či jiné formy nápravy poválečného odsunu“ a striktním viděním sudetských Němců jako kterýchkoli jiných Němců. Právě tento závažný aspekt Havlova projevu v pražském Karolinu přispěl nepochybně ke vzniku iniciativy Smíření $95 .{ }^{31} \mathrm{~V}$ kontrastu k Havlově projevu tato společná česko-německá občanská iniciativa ve svém prohlášení považovala za nezbytnou „zejména formulaci společného stanoviska k problematickým rozhodnutím minulosti, jež bude opřeno o všeobecně uznávané normy lidských a občanských práv“, která by měla vzejít ze společného jednání české vlády a politické reprezentace sudetských Němců. V prohlášení navrhovaná společná spolupráce měla zahrnovat i možnost návratu sudetských Němců do České republiky, s tím, že mají nárok na stejná práva jako občané ČR. Bylo též navrženo vytvoření „,společné česko-německé nadace se státní účastí za účelem podpory konkrétních projektů v českém pohraničí“. Právě myšlenka př́mého jednání se sudetskými Němci a nahlížení „problematických rozhodnutí minulosti“ perspektivou „všeobecně uznávaných norem lidských a občanských práv“ zapůsobila jako rudá barva na býka, vyústila $\mathrm{v}$ až nenávistné útoky na osobnosti spojené s iniciativou Smíření $95^{32}$ a byla doprovázena rozsáhlou jednoznačnou reakcí v médiích, implikujících dokonce „zradu národních zájmư“. Stalo se poměrně zřejmým, že vyrovnání se české společnosti s otázkou sudetoněmeckých Němců není jen problémem hledání společného stanoviska s Němci (at' již se sudetskými nebo s Němci obecně), ale především do značné míry otázkou vnitřní , „česko-české“ rozpravy, ${ }^{33}$ která by měla předcházet česko-německému vypořádání se s minulostí. Centrální pozici vyrovnání se s odsunem v „,̌esko-české“ diskusi potvrdilo i další prohlášení, tentokráte již pouze českých intelektuálů nazvané „Cesta ke smíření“. Toto prohlášení explicitně konstatovalo, že „, prvé řadě jde o odsouzení vyhnání sudetských Němců z Československa a všeho, co s tímto osudovým aktem souviselo“ (Lidové noviny 30. 2. 1996, in Pithart a Př́hoda 1998: 136-137), a v této souvislosti jednoznačně odmítlo prosazování tzv. „tlusté čáry“ za minulostí jako prostředku k ignorování otevřených problémů mezi Čechy a Němci. „Česko-německá deklarace o vzájemných vztazích a jejich budoucím rozvoji“‘34 podepsaná 21. ledna 1997 v Praze vládami ČR a NSR nakonec něco z klíčových návrhů iniciativ „Smíření 95“ a "Cesty ke smíření" obsáhla. Česká strana v samostatném paragrafu, obdobně jako strana německá (paragraf předcházející ten český), ve společné 
deklaraci „lituje, že poválečným vyháněním, jakož i nuceným vysídlením sudetských Němců z tehdejšího Československa, vyvlastňováním a odnímáním občanství bylo způsobeno mnoho utrpení a křivd nevinným lidem, a to i s ohledem na kolektivní charakter přisuzování viny“. Specificky je zmíněna problematika obzvláště extrémních př́padů: „Zejména lituje excesů, které byly v rozporu s elementárními zásadami i s tehdy platnými právními normami, a nadto lituje, že bylo na základě zákona č. 115 z 8 . května 1946 umožněno nepohlížet na tyto excesy jako na bezprávné a že následkem toho nebyly tyto činy potrestány.“

Deklarací byl zřízen „Česko-německý fond budoucnosti“, podobně v článku VI. deklarace je reflektován požadavek iniciativy „Smíření 95 “ ohledně získání nediskriminovaného postavení sudetských Němců v České republice poukazem na možnosti výdělečné a podnikatelské činnosti v rámci existujícího uspořádání vztahů ČR - EU a volný pohyb po vstupu ČR do EU.

Deklarace byla kritizována $\mathrm{z}$ různých stran a mnohé útoky byly značně sofistikované (například Petice podaná Poslanecké sněmovně a Senátu skupinou převážně akademiků, včetně historiků prof. R. Luži - autora první emigrantské monografie na téma odsunu z roku 1954, prof. J. Valenty a dr. B. Čelovského). Jednoznačně byla odmítnuta krajními stranami - Komunistickou stranou Čech a Moravy a pravicově radikálním Sdružením pro republiku - Republikánskou stranou Československa - a Petr Uhl v jednom ze svých komentářủ konstatoval, že nacionalisté na obou stranách česko-německé hranice se dostávají do izolace (in Pithart a Př́hoda 1998: 204). Přestože se v souvislosti s akceptováním deklarace objevilo i více ohlasů zdůrazňujících totalizační efekt odsunu na politický systém poválečného Československa a jeho dekompozici a poukazujících na legitimizační roli, kterou v komunistickém systému sehrávala „sudetoněmecká hrozba“ “, ${ }^{35} \mathrm{v}$ široké veřejnosti, včetně její intelektuální části, převládl značně negativistický př́stup k deklaraci. Zásadním bodem prritom byla otázka sudetských Němců a omluvy za poválečné násilí na nich spáchané.

S odezněním diskusí předcházejících a bezprostředně následujících podepsání deklarace, které mělo zásadně přispět $\mathrm{k}$ obratu směrem $\mathrm{k}$ budoucnosti v česko-německých vztazích, se mohlo zdát, že odmítání omluvy za násilí v době odsunu odstoupí k okrajům politického spektra.

Sudetoněmecká otázka a poválečné násilí se opětovně prosadily do centra politického dění s přibližováním se jednání ČR o vstupu do EU, s tím jak se začaly ze strany politických reprezentací sudetských Němců objevovat hrozby ovlivnění př́istupových jednání a ratifikace vstupu ČR, at' již v rámci EU (v Evropském parlamentu) či jednotlivých zemí (rakouský a německý parlament). Klíčovou otázkou se i ve vztahu k unijnímu zákonodárství stala problematika „Benešových dekretư“, jejichž aplikací došlo k "utrpení a křivdě“, kterých česká strana litovala v deklaraci z roku 1997, v souvislosti s čímž byl vysloven ze strany sudetských Němců požadavek anulovaní těchto dekretů. Tímto na české politické scéně došlo k návratu sudetoněmecké otázky do mainstreamu politického dění, médií a nejširší veřejnosti. Zpochybnění „Benešových dekretư “36 přitom vedlo k opětovnému aktivnímu obhajování legality odsunu nejen širokou veřejností, ale i klíčovými politiky. Tento „backlash“ vedl k jisté reinterpretaci českého omluvného paragrafu ve společné Deklaraci z roku 1997, respektive k „vyjasnění“ toho, co je touto omluvou myšleno, at' již mezi politiky nebo v rámci nejširší veřejnosti. Ačkoli první ćást - věta III. paragrafu deklarace - vyznívala jako omluva za odsun jako celek ${ }^{37}$ a druhá část jako politování obzvláště násilných a zločinných „excesư“", ${ }^{38} \mathrm{v}$ „Benešovy dekrety“ obha- 
jujícím legalistickém pojetí se odsouzení a lítost omezila na „excesy“ jako ilegální a zločinné akty narušující oprávněnou aplikaci dekretů, které jsou takto interpretovány jako bezprostřední konsekvence válečného dění. Právě na platformě tohoto vidění „Benešových dekretư“ a odsunu Němců z Československa, které se shoduje s tradiční interpretací problematiky vysídlení německé menšiny KSČM (dříve KSČ), došlo v průběhu předvolební kampaně do Poslanecké sněmovny v roce 2002 k paradoxní situaci, kdy se Občanská demokratická strana, stavíce se za agendu „národních zájmü“ $\mathrm{v}$ intencích této interpretace „Benešových dekretư“ dostala $\mathrm{k}$ boji proti „německému revanšismu“ a „,klerikalismu některých českých politických stran“ (myšleno KDU-ČSL, US-DEU) a iniciovala s podporou KSČM práci na společném usnesení sněmovny na obranu „Benešových dekretư“ (Usnesení Poslanecké sněmovny Parlamentu České republiky ze 49. schůze $\mathrm{k}$ dekretům prezidenta republiky z 23. dubna 2002). ${ }^{39}$

\section{3. „Zásady“ společenské reflexe}

Pithart a Př́hoda (1998: 223-228) dokumentovali takovéto „sjednocování veřejného mínění“, „tvorbu situačního většinového konsensu“, „tj. sblížení skupin jinak mimoběžných“ explicitně na př́ikladu periodického tisku v období let 1990-1997. Jevy, které vytvářejí předpoklady pro tento proces lze shrnout do několika bodů:

a) konstantní dlouhodobě přetrvávající obraz nepřítele: sudetští Němci zůstávají těmi válečnými a odsunovými „sudetskými Němci“, bez ohledu na generační obměny;

b) diskuse o tématu odsunu má dlouhodobě charakter ,jednorázových polemických střetnutí “ bez názorových posunů a korekcí, ke kterým by mělo docházet s rozvojem rozpravy;

c) emotivnost v souhře s absencí informací nezbytných pro kvalifikovanou diskusi - užití klišé (,většina sudetských Němců se rozhodla pro Hitlera a nacismus“, „Postupim“ - nedostatek jakékoli bližší charakteristiky dané události a bližších okolností);

d) ačkoli projevy jsou velmi intenzivní, zaujaté, osobní a charakteristické vypjatou konfrontací, zahrnují minimum reminiscencí, skutečných obrazů a reálií vlastního odsunu .

Převládající ráz rozpravy o odsunu je dále charakterizován Pithartem a Př́ihodou jako populistický (,emotivita převažuje nad racionalitou“, „paušalizující konstatace“, „necitelnost k utrpení ,těch druhých““, „stereotypní výpovědi jako argumenty“, „subjektivní prožívání“ - „absolutizace osobního strádáni““, „emoční stereotypy“, „lpění na tradovaných klišé“), tento charakter rozpravy souvisí i s nezájmem tisku o německé a sudetoněmecké př́ispěvky (s několika výjimkami), nemluvě již o absenci prezentace nezávislého zahraničního náhledu na domácí problematiku (Pithart a Př́íhoda 1998: 225-226).

Do tohoto charakteru rozpravy zapadá i role „sehraná“ historiky. Ačkoli se historici často ohrazovali proti diletantismu publicistů, $v$ převážné většině př́padů se ukázalo, že jejich řady se diferencovaly v souladu s děním v širší veřejnosti a podle kriterií nikoli pouze profesně historických (Pithart a Př́hoda 1998: 225-226).

Tato skutečnost se odráží $\mathrm{v}$ současné a nedávné historické produkci zaměřené na problematiku odsunu. Nedávno vydané přehledové publikace věnované odsunu Němců z Československa (pravděpodobně první po Staňkově [1991] a Kučerově [1991] publikaci, nejsou-li brány v úvahu sborníky) ${ }^{40} \mathrm{~s}$ sebou nesou v rozsáhlé míře étos takovéhoto umělého „,sjednocování veřejného mínění“. 
Publikace Téma: Odsun-Vertreibung: Transfer Němců z Československa 1945-1947 (Z. Beneš, J. Kuklík ml., K. Kural, J. Pešek, 2002) vydaná Státním pedagogickým nakladatelstvím a určená učitelům základních a středních škol - zřejmě v rámci „legitimizování“ principu transferu - takto dosti účelově a s relativizujícím efektem v kapitole „Mezinárodní souvislosti odsunu“ řadí mezi příklady nucených migrací poměrně jednoznačné př́pady záměrné a plánované genocidy realizované tureckou a sovětskou vládou (likvidace arménské menšiny v Turecku, některých kavkazských národů, krymských Tatarů, povolžských Němců sovětskou vládou) vedle represivních a násilných transferů genocidního charakteru (transporty Židů, Poláků, př́slušníků pobaltských národů do pracovních táborů na Sibiř) a přiřazuje tyto arbitrární a zločinné akty k výjimečným př́padům migrací, které se uskutečnily v meziválečném období - jako pokus řešit problém menšin (tedy v podstatě k jedinému známému případu výměny obyvatelstva mezi Tureckem a Řeckem po 1 . světové válce). ${ }^{41}$ Toto neporozumění rozdílům a odlišnému charakteru zmíněných událostí osvětluje přístup a metodologická východiska autorů k vlastní problematice odsunu v poválečném Československu.

Neprofesionalizmus autorů publikace naznačují konkrétní slovní charakteristiky a popis historických událostí v souvislosti s odsunem, jako naprŕklad formulace „Stalinovu vedení se po přepadu Sovětského svazu německou armádou podařil husarský kousek: Sověti postupně dotlačili západní spojence k uznání ruské části“ paktu MolotovRibbentrop (Beneš a kol. 2002: 38). Po podkapitole „Psychologická situace na konci války a těsně po ní", popisující zločinné jednání okupačních institucí v poslední fázi okupace a další faktory ovlivňující psychologickou situaci obyvatelstva, přechází šedesátistránková publikace věnovaná „transferu Němců z Československa 1945-1947“ na straně 40 k vlastní problematice odsunu Němců v období let 1945-1947. Přestože 16 stran věnovaných odsunu jako takovému je historiograficky poměrně věcným obrazem událostí, často čtenáře zarazí jazyk použitý k charakteristice těchto událostí. Například o motivech německých antifašistů, které je přiměly k odchodu z ČR, ${ }^{42}$ je uvedeno: „Vedla je i myšlenka výstavby nového, socialistického Německa. V tom je podporovala také KSČ a Jednotná socialistická strana Německa (SED) v nich získala mnohdy ideologicky dobře připravené funkcionáře“ (Beneš a kol. 2002: 48). Podobně o represivních postupech komunistického režimu v období 1950-1951 (Červeným křížem zprostředkované vystěhování tisíců Němců do NSR) se píše: „Šlo opět především o kvalifikované pracovníky, takže celou akci československá vláda z hospodářských a samozřejmě i politických důvodů zastavila“" (Beneš a kol. 2002: 47). Dehonestující jazyk odpovídající spíše agitačním brožurám z období komunistického režimu je užít i pro charakteristiku sociálně-ekonomické destrukce bezprostředně následující v důsledku odsunu: „Nahradit tyto ztráty se ukázalo jako mimořádně náročný a dlouhodobý úkol - odtud ostatně také pramení například akce náboru do dolů z roku 1949“ (Beneš a kol. 2002: 46-47). Zdá se, že autoři, či někteří z nich, se nedokáží zbavit dehumanizujícího komunistického jazyka, což nezbytně nemusí odsouvat věcnou podstatu jejich historického bádání. Ovšem trend arbitrárně-kolektivistického typu uvažování vychází mimo hranice newspeaku komunistického režimu: „Příklon k nacismu byl v podmínkách demokratické ČSR - přes všechny nedostatky její národnostní politiky - koneckonců svobodnou volbou. A jak se ukázalo, bylo to rozhodnutí, které mělo mít katastrofální následky“ (Beneš a kol. 2002: 58). 
Přestože autoři svoji přehledovou publikaci určenou pro učitele zaštitují rozsáhlými citacemi materiálů a závěrů „Společné československo-německé komise historiků ${ }^{\text {“43 }}$ (především v závěrečné části textu věnované interpretaci odsunu), znaky „sjednocování veřejného míněni“ $v$ intencích komunistické interpretace válečných a bezprostředně poválečných československých dějin u této publikace přetrvávají. A to obzvláště vzhledem $\mathrm{k}$ faktu, že publikace nijak neregistruje problematiku totalitních tendencí v poválečném Československu, boje o politický vliv a roli, kterou v tomto dění agenda a realizace odsunu sehrávala (klientelistický charakter komunisty dominové redistribuce československým Němcům zabaveného movitého i nemovitého majetku a výrobních zdrojů vedoucí následně $\mathrm{k}$ enormnímu nárůstu preferencí KSČ v pohraničních oblastech). ${ }^{44}$ Publikace sice zahrnuje obecnější kontextuální kapitoly, ty jsou ovšem věnované problematikám dlouho předcházejícím vlastnímu odsunu odehrávajícímu se v letech 1945-1947.45

Přehledová př́ručka Cesta $k$ dekretům a odsunu Němců (Němeček a kol. 2002) ${ }^{46}$ zvoleným určením událostí i jejich charakteristikou a zařazením do historického kontextu, včetně používané terminologie, se prríliš neliší od pojetí príruček publikovaných $\mathrm{k}$ tomuto, pro počátky komunistického režimu klíčovému, období před rokem 1989 (prezentace rozsáhlých komunistických a demokracii zpochybňujících „výdobytkư“ na londýnské vládě bez jakýchkoliv výhrad, třeba i těch čistě formálních, které by naznačovaly jejich problematičnost; použití zkratky „tzv.“ při zmiňování klíčových, k totalitnímu režimu směřujících, kroků a programů jako v př́padě „Košického vládního programu“ apod.).

Historické produkci je pochopitelně možné věnovat pozornost rozsáhleji, i když pro naznačení obecnějšího trendu v české historiografii a hlediska chápání soudobých dějin jsou výše uvedené př́klady přehledových publikací dostatečně ilustrativní. ${ }^{47}$ Monografických publikací věnujících se primárně odsunu a jeho vlastnímu průběhu, odhlédneme-li od studií věnovaných genezi a prosazování myšlenky vymístění československých Němců v kontextu působení československé exilové vlády či textů osvětlujících průběh jednání na Postupimské konferenci ve vztahu $\mathrm{k}$ odsunu, ${ }^{48}$ je ve skutečnosti pouze několik. Zdá se, že mnozí z etablovaných a prominentních historiků věnujících se problematice česko-německých vztahů se monografickému zpracování problematiky samotného odsunu vyhýbají, ačkoli se detailně věnují obdobím bezprostředně předcházejícím či následujícím tuto kritickou kapitolu v dějinách, nejen československých Němců.

Klíčovým problémem se jeví nedostatečný důraz kladený na zařazení vlastního odsunu do kontextu vzniku, vývoje a přechodu mezi totalitními režimy (od nacistického okupačního typu k sovětskému typu), které jsou v nenacionálně orientované historiografii hlavním determinantem v nedávných dějinách střední a východní Evropy. (Nejde tedy o obvyklé rozpracování argumentů registrujících detailně problémy mnohonárodnostního soužití, jdoucí hluboko do historie Rakousko-Uherska a habsburské monarchie, tak jak převažuje v praxi české historiografie.) Pro kontext poválečného vývoje v Československu, v souvislosti s odsunem a represemi celých skupin obyvatel, at' již československými nebo sovětskými orgány, je českou domácí historiografií poněkud opomíjena „continuity thesis“49 (viz výše DanubiusMlynárik 1990, teze č. 1, 2b, 2c a 8 [původně Svědectví 54/1978]). To je o to překvapivější, že pro další středoevropské národní historiografie po roce 1989 je tato teze charakteristická a převažující. ${ }^{50}$ Toto je dáno nepochybně explicitnějším vlivem a účastí Sovětů v přechodu 
k totalitnímu režimu sovětského typu v těchto zemích (nejvýrazněji zřejmě v Polsku). Ale právě problematika odsunu československých Němců je do značné míry oním chybějícím kamenem v mozaice vysvětlující přináležitost československého vývoje, jakkoli značně specifického, do kontextu kontinuity přechodu mezi nacistickým okupačním a komunistickým režimem ve střední Evropě.

Represivní aparát vzniklý za účelem eliminace základních práv př́slušníků německé menšiny a dalších „,nepohodlných“ skupin obyvatelstva a budovaný v souladu s modelem sovětských represivních složek (konkrétně se jednalo o tzv. „asistenční oddíly“ Svobodovy armády v pohraničí a šířeji o nově konstruovaný a enormně narůstající bezpečnostní aparát komunisty kontrolovaných a otevřeně politizovaných ministerstev vnitra a časem i ministerstev obrany; obecným př́íladem je komunisty ovládnutá veřejná správní struktura národních výborů a zástupných orgánů $\mathrm{v}$ pohraničí atd.) bezprostředně předjímal nástup elementů totalitního režimu (včetně vlastních represí a eliminace vlivu nekomunistických aktérů ve společnosti, ekonomice a politice).

V současné české historiografii zabývající se poválečnými dějinami je patrné oddělení problematiky dekompozice poválečného režimu a nástupu komunistické totality a problematiky poválečných represí neslovanského obyvatelstva na Československém území. Existuje tak partikulární historické téma registrující mechanizmy degradace demokratických východisek poválečného režimu komunistickými a agenturními elementy v různém rozsahu spojenými se Sověty; ${ }^{51}$ odděleně od něj se historici zaměřjí na problematiku odsunu, často jakoby v mocensko-politickém vzduchoprázdnu. Jak dokládají práce T. Staňka (1991, 1996, 2002), právě $\mathrm{v}$ souvislosti $\mathrm{s}$ poválečnými, převážně národnostně danými, represemi a systémem mimosoudních-retribučních mechanizmů, se objevují první známky stalinistického systému, tak jak v monstrózní obludnosti vyvrcholily v 50. letech (oblasti spadající pod Ministerstva vnitra a obrany, dezinformační kampaně Ministerstva informací provázané s těmito silovými ministerstvy).

\section{Události let 1945-47 jako zdroj kolektivního traumatu}

Od roku 1989 bylo v České republice publikováno množství osobních vzpomínek sudetských Němcủ, ${ }^{52}$ zahrnujících individuální svědectví o poválečných represích československých Němců, a vlastním průběhu jejich odsunu, neomezujících se ale často jen na tuto brutální fázi a popisujících celoživotní pokusy o osobní individuální vyrovnání se s vyhnáním a s návratem do rodné země a traumaty s tím spojenými. ${ }^{53}$ Většina těchto individuálních vzpomínek zahrnuje popis arbitrárního násilí na konkrétních lidech, jenž jsou jmenováni konkrétními jmény - násilí zakončeného fyzickou likvidací vyvolávajících vzpomínku na svévolné násilí nacistických zločinců. ${ }^{54}$ Tyto konkrétní oběti, každá stále nesená v individuálních pamětech a vzpomínkách spolu s konkrétními obrazy jejích vrahů, dodnes často spočívají v neoznačených hrobech.

Důsledky odsunu československých Němců lze jednoznačně předestř́t jako rozsáhlé kolektivní trauma. Sztompka (2000: 449-466) explicitně zmiňuje „,násilnou migraci, deportaci“ jako charakteristicky traumatickou událost - měřítkem a hloubkou všezahrnující, přicházející z vnějšku, nepředpokládatelnou a vytvářející potenciál pro „kulturní trauma“. Událost 
zasahující vyhraněnou etnickou skupinu s sebou nese výrazný transgenerační potenciál. Volkan and Itzkowitz (2000: 227-247) vyvinuli koncept „,vybraného traumatu“ k osvětlení vývoje kolektivní reprezentace sociálně nebo etnicky vyhraněné skupiny jako oběti minulých ztrát a ponížení. ${ }^{55}$ Takto vymístěné a geograficky dezintegrované společenství sudetských Němců je výrazně determinováno transgeneračním přenosem. $V$ př́padech takovýchto historických situací je sociální identita strukturována v souvislostech historického ponížení a potřeby nápravy minulých špatností. Ačkoli si skupina záměrně nevolí pocit viktimizace, ztráty a ponížení jsou transformovány v kulturně vázané narace, které se stávají bezprostřední součástí sociální identity (Volkan a Itzkowitz 2000).

Na druhou stranu lze podobně o neméně závažném a klíčovém traumatu hovořit i ve vztahu k českému společenství, původci drastické události odsunu. Zde došlo - na celospolečenské úrovni po roce 1989 - k vyplynutí nesouladu mezi fakty vztahujícími se k současnosti (a s ní spojeným základním společensko-kulturním předpokladům - vytváření pluralitní demokratické společnosti) a minulosti (kolektivní násilí spojené s prosazováním totalitních tendencí vedoucích $\mathrm{k}$ likvidaci pluralitního a demokratického systému). Jak indikuje Sztompka (2000), takto odhalená traumata s sebou nesou narušení klíčových kulturních předpokladů a základů identity, tj. vyvolávají reakce, které lze nahlížet paralelně s Mertonovým rozlišením různých způsobů adaptace $\mathrm{v}$ prípadech anomie.

Výše v textu představené trendy, charakterizující diskusi o vymístění československých Němců nejen $\mathrm{v}$ českých mediích, ale i v nedávno publikovaných odborně-historických textech, jsou projevy takovýchto adaptačních reakcí. Ve společenském spektru lze identifikovat celou škálu těchto reakcí. Od pokusů inovace, umožňujících vyrovnání se s minulostí (spíše menší část veřejnosti), přes uplatnění prvků ritualizace (udržování obrazu nepřítele, užití klišé a stereotypů), či stáhnutí se (nevěnování pozornosti či omezení pozornosti v rámci prezentace širšího kontextu či jiných dávno známých a rozsáhle a dlouhodobě akcentovaných traumatických událostí), až po jednoznačné odmítnutí (extrémistické a populistické reakce). Právě dlouhotrvající a převažující užití pasivních adaptačních technik (ritualizace, stáhnutí se) nasvědčuje dlouhodobé perzistenci traumatu a neschopnosti se s ním vypořádat. Přetrvávání traumatu se manifestovalo také v politické polarizaci. Zde je ovšem nutné zaznamenat závažný posun v českém politickém kontextu. Jestliže aktivní odmítavá reakce byla v průběhu 90. let primárně spojena s extremistickými aktéry (SPR-RSČ, KSČM), na přelomu tisíciletí došlo k prosazení této adaptační reakce i do mainstreamu české politiky; zřejmě také v souvislosti se snahou ODS převzít voliče zaniklé SPR-RSČ a s nárůstem podpory KSČM. ${ }^{56}$ Obvyklá polarizace mezi politickým mainstreamem a extremismem se takto posunula do prostoru samotného mainstreamu (ČSSD, ODS versus KDU-ČSL, US) a odsun a vypořádání se s ním se staly předmětem „kulturní války“57 ve Smelserově smyslu (v tisku: 32) .

\section{Závěr}

V průběhu 90. let a na začátku současné dekády lze registrovat posuny v chápaní problematiky odsunu. První fáze je charakterizovatelná směřováním $\mathrm{k}$ odmítnutí represe na základě principu kolektivní viny, k uznání zločinného charakteru tohoto vymístění a uvědomování si jeho nezastupitelného významu při zavádění komunistického totalitního reži- 
mu, tak jak vyplynulo z diskuse disidentských a emigrantských historiků vedené do začátku 90. let (včetně akcentování tohoto posunu i politickým mainstreamem v určitém kontrastu k populistickému marginésu - Sládkově SPR-RSČ, KSČM). V druhé fázi, datující se od poloviny 90. let, je zjevný postupný posun zpět ve směru komunisticko-režimního pojetí vymístění Němců, až k jeho výraznému etablování se v politickém mainstreamu v souvislosti s volbami v roce 2002. ${ }^{58}$

Počáteční část textu se soustředila na průběh mediální a společenské diskuse o Jedwabnem na historickém pozadí vztahů mezi polským a židovským obyvatelstvem během války a v době vlády komunistického režimu. Pokusila se osvětlit, jak je v moderních dějinách dlouhodobě konfrontačně strukturovaný charakter těchto vzájemných vztahů zbavován svého výbušného potenciálu a stává se předmětem širší reflexe. Ta umožňuje nejen historický návrat židovské menšiny a boj s fyzicky dokonaným vymístěním, ale přispívá i k vytváření post-nacionálního společenství netolerujícího ideu násilného vymístění.

Obrácením pozornosti k otázce vymístění Němců z Československa nejde o historické srovnávání prrípadů vlastního vymístění dvou různých menšin,. ${ }^{59}$ Jde především o soustředění se na vypořádávání se jednotlivých společenství s traumatem vymístění, užití těchto vymístěných menšin v legitimizování komunistického totalitního režimu, zaměření se na přetrvávající rezidua této přidělené role v současném politicko-společenském kontextu a na jejich nárůst a posun z politického marginésu do mainstreamové politiky v prŕípadě České republiky.

\section{Poznámky}

1 Zde je myšlen pozdější kolektivní traumatický efekt, se kterým se musí vypořádat iniciátor násilí proti skupině obyvatel po dlouhodobé represi tohoto násilného aktu, a to prostřednictvím kolektivní reflexe, otevřené debaty a zpětného „projiti““ vlastních událostí (aplikujeme-li psychoanalytickou teorii strukturace traumatu).

2 O knize podrobněji v rozhovoru J. T. Grossa pro Literární noviny nazvaném „Je lépe být obětí než pronásledovatelem“, $L N$ 19/2002, s. 5.

3 V předválečném Polsku náležely pogromy, fyzické útoky, ničení a krádeže majetku ke každodennostem polsko-židovského soužití (jenom v letech 1935-1937 došlo v Polsku ke 150 pogromům). Antisemitismus byl rozšiřren ve všech sociálních vrstvách, včetně vládnoucích elit. Tedy například i v Jedwabnem organizovala část lokálních politiků - využivajíce polskou chudinu, nezaměstnané a kriminální živly - bojkoty židovských obchodů, živností a tržních stánků (,straganů“ v době trhů), které běžně přerůstaly ve fyzické konfrontace a ničení či rabování zboží (v předválečném Jedwabnem došlo i ke konfrontaci mezi polskými bojůvkami a židovskou sebeobranou obchodníků a živnostníků, která se neobešla bez střelby). Zdá se, že toto byl obvyklý obrázek ve východní - „kresové“ - části Polska, kraji „štetlư““ - malých chudých městeček s výrazným židovským živlem.

Antisemitské akce ale nebyly charakteristické pouze pro tyto agrární nerozvinuté části Polska. V mnoha urbanistických centrech, včetně Varšavy, docházelo k útokům národoveckých bojůvek na Židy na ulicích a k organizování protižidovských demonstrací. Lidé židovského původu byli konfrontováni s celou řadou omezení přístupu ke vzdělání - jako byly kvóty při přijímání na univerzity a značně segregovaný školní systém. Navzdory těmto diskriminačním opatřením byla vrstva židovské inteligence tradičně silná a její význam sahal daleko za hranice židovského společenství.

4 Některé akce byly církevními hodnostáři považovány za provokace komunistického bezpečnostního aparátu. 
5 D. Jarosz a M. Pasztor (1995) rozsáhle dokumentují tento jev ve studii věnované ,,politice komunistických vlád ve světle fám a pověstí v období 1949-1956“.

6 Přes rozpor, které toto spojení ve světle anti-židovských kampaní odehrávajících se na přelomu 40. a 50. let v SSSR s sebou neslo.

7 Zenon Nowak na VII. plénu Ústředního výboru Polské sjednocené dělnické strany poukázal na skutečnost, že anti-židovské motivy sehrávají jistou roli v boji probíhajícím uvnitř stranického vedení (Jarosz a Pasztor 1995: 135).

$8 \quad$ Toto se odráží i v obecném povědomí - např́íklad jeden z polských knězů v okrese Gryfino spekulujíc o nástupnictví po Bierutovi uvedl, že „nejlépe na jeho pozici by se hodil Jakub Berman, ale vzhledem $\mathrm{k}$ jeho rasovému původu pravděpodobně nebude zvolen, protože by došlo ke střetu s veřejným míněním. Vzhledem k tomu bude vybrán zřejmě Frantisek Mazura“ (Jarosz a Pasztor 1995: 204).

9 Zpočátku měly tyto události mnohdy poněkud tragikomický charakter; např́iklad projednávání v tiskovém oddělení Ústředního výboru Polské sjednocené dělnické strany pití vodky na oslavu arabsko-izraelského míru, tj. prohry arabské strany, v redakci týdeníku pro ženy „Přítelkyně“. Nakonec v roce 1968 došlo k vyhození větší části redakce a k vyloučení vyhozených členek ze strany.

10 Tato emigrační vlna zahrnovala enormní intelektuální potenciál. K osobnostem, které v té době emigrovaly, patří z oblasti sociálních věd např́klad Leszek Kolakowski, Zygmunt Bauman, a nakonec i Jan Tomáš Gross, autor „Sousedů“, patřil ke studentům Varšavské univerzity, kteří, v souvislosti s dlouhotrvajícími represemi studentů následujícími po březnových událostech, byli nuceni odejít.

11 Rozsáhlá diskuse, která ke knize „Sousedi, historie záhuby židovského městečka“ proběhla v polských mediích, je zaznamenána na webových stránkách vydavatele - kulturní nadace Pogranicze (www.pogranicze.sejny.pl/jedwabne/index.html) - a zahrnuje všechny materiály publikované v polských denících, týdenících a zbývajících periodicích na téma Jedwabnego a s ním souvisejících diskusí polsko-židovských vztahů.

12 Obzvláště skandální je činnost místního kněze v Jedwabnem Edwarda Orlowského, který otevřeně vyjadřuje antisemitské názory a rozšiřuje protižidovské tiskoviny. Podobně lomžinský biskup, do jehož diecéze patři Jedwabne, tvrdí, že odhalení ohledně Jedwabnego jsou předem zaranžovanými židovskými útoky, které mají donutit Polsko k finančním kompenzacím, a že Židé spolupracovali se Sověty, a proto by měli oni prosit o odpuštění Poláky. Polská katolická hierarchie nevyužila svých pravomocí a odpovědnosti, aby tomuto skandálnímu jednání svých lokálních představitelů zamezila. Dvanáct z nejagilnějších účastníkủ likvidace židovských obyvatel bylo po válce v několika různých procesech souzeno na základě svědectví jednoho ze sedmi přeživších židovských obyvatel.

14 Podrobněji o prof. T. Strzemboszovi a jeho názorech viz text Artura Domoslawského „Kustosz Polski niewinnej“, Gazeta Wyborcza , 19-20. května 2001, s. 14-16.

15 Grossova kniha vyprovokovala rozsáhlé vyšetřování, které nakonec zahrnulo i exhumaci části obětí. Byly objeveny nábojnice, což mohlo svědčit o německé účasti, médii byly bezprostředně zprostředkovány zvěsti o omylu. Později se ukázalo, že různé nábojnice nemají s tragickými událostmi z července 1941 nic společného (v okolí Jedwabnego došlo za 1. světové války a v roce 1944 k rozsáhlým bojovým akcím).

16 Včetně sporu o text na památníku na místě stodoly, v níž byla velká část obětí upálena. Navrhovaný text „Na památku Židům z Jedwabnego a okolí, mužům, ženám a dětem, spoluhospodářům této země, zavražděným a zaživa upáleným na tomto místě 10. července 1941. Na výstrahu př́itomným, aby německým nacismem zažehnutý hřích nenávisti již nikdy neobrátil proti sobě obyvatele této země“ byl po protestech rodin obětí a židovských organizací redukován pouze na první větu. 
17 Referujíce $\mathrm{k}$ původním československým občanům německé národnosti v období do ukončení jejich odsunu, je používáno ve shodě s Danubiusem-Mlynárikem označení „českoslovenští Němci“ (včetně Němců z vnitrozemských jazykových ostrovů a velkých městských center). Vžitým označením „sudetští Němci“ je referováno k distinktivní skupině vysídlených Němců v Německu a Rakousku.

18 Př́ispěvky do diskuse včetně Danubiusova-Mlynárikova původního textu byly shrnuty v knize Čě̌i, Němci, odsun. Diskuse nezávislých historiku (Černý a kol. 1990).

19 Citace z Danubiusova-Mlynárikova textu byly převedeny do češtiny.

20 Bláhovost př́iklonu prezidenta Beneše k Sovětskému svazu byla široce kriticky reflektována $\mathrm{v}$ řadách českých a slovenských pracovníků a spolupracovníků emigrantské vlády v Londýně již v čase přípravy první návštěvy prezidenta Beneše v Moskvě (viz např́ílad Fischl 2003) a také byla s obavami předpovídána britskými partnery československé vlády.

21 V této souvislosti je nutné připomenout ztrátu Zakarpatské Ukrajiny a faktický neúspěch obnovy Československa v předmnichovských hranicích právě v důsledku „zadluženi““ se Sovětskému svazu i v bezprostřední souvislosti se získáním Stalinovy podpory pro odsun československých Němců.

22 Nelze nevzpomenout případu př́slušníka komunisty ovládaného a na sovětské zpravodajské služby napojeného Obraného zpravodajství poručíka Karola Pazúra, bývalého příslušníka Hlinkovy gardy, který nechal v Horních Moštěnicích u Přerova 18. června 1945 povraždit transport 265 karpatských Němců, převážně žen (120) a dětí (74) (Staněk 1996: 118-121), nebo také Bedřicha Pokorného bývalého zpravodajského důstojníka předválečné armády a za války pravděpodobně spolupracovníka brněnské SD, kandidovaného brněnskou buňkou KSČ na pozici velitele „Národní bezpečnostní stráže" pro Moravu, který byl pověřen vedením odsunu brněnských Němců (blíže Hertl 2001: 245-247) a který později, po odstranění plk. Bartíka prostřednictvím vykonstruovaných obvinění za použití konfidenta Gestapa, převzal kontrolu zpravodajské sekce Ministerstva vnitra a sehrál klíčovou roli v systémovém využití retribučních procesů komunisty v procesu nastolování totalitního režimu (masové obviňování odpůrců KSČ těsně před volbami za účelem zbavit je hlasovacího práva nebo kauzy obvinění důležitých aktérů domácího odboje, například Václava Krajiny apod.). Mechanismy řízeného působení a záměrné infiltrace „,pochybných existenci““v obnovovaných státních a bezpečnostních orgánech pod komunistickou záštitou rozsáhle popsal T. Staněk (1991, 1996 a 2002).

23 Mnohým z místně klíčových reprezentantů nacistického režimu se povedlo uniknout z působnosti československých soudů prostřednictvím zařazení do divokých odsunů v roce 1945.

24 Emanuel Mandler vyčíslil, že zhruba 2 miliony z odsunutých československých Němců, obviňovaných $\mathrm{z}$ rozbití republiky $\mathrm{v}$ době Mnichova, nemohly být za toto učiněny odpovědnými vzhledem $\mathrm{k}$ tomu, že jim v kritické době bylo méně než 15 let nebo patřili mezi $10 \%$ voličů sociálně demokratické strany (Mandler 2001: 151-152).

25 Vyostřená diskuse se neomezila pouze na disent, ale zasáhla např́iklad i redakci Svědectví. Redakční rada se distancovala od textu „Tézi o vysídlení československých Nemcov“ (Pavel Tigrid je nechal otisknout bez vědomí rady), člen rady Radomír Luža, který byl autorem první monografické publikace na téma odsunu (Odsun sudetských Němcio, New York 1954), rezignoval na svoji práci $\mathrm{v}$ redakční radě.

26 V jistém momentu padl dokonce návrh, aby se staly dokumentem Charty 77 podobně jako jiné zprávy o kontroverzních a v tehdejším kontextu konsternujících tématech ("cikánská“" problematika, přítomnost sovětských jaderných zbraní apod.), ale ukázalo se, že „Tézy“ jsou př́liš ožehavé i pro mnohé z řad chartistů, obzvláště pro ex-komunisty (například M. Hubla). Blíže viz například Abrams 1995.

27 Připomeňme prostor a kritickou pozornost věnovanou odsunu týdeníky Obzory a Dnešek v letech 1945-1948, tj. v době průběhu odsunu. 
Poněkud překvapivě, donedávna striktně „ekonomicky a technokraticky orientovaný pragmatik“ Václav Klaus se 28. záŕí 1993 objevil na slavnostním aktu na Vyšehradském hřbitově.

„Fatální selhání velké části našich občanů německé národnosti, kteří před demokratickým dialogem a tolerancí dali přednost diktatuře“, ,...jednoznačné odmítnutí všech pokusů vydolovat z dávných historických událostí či nespravedlností celý soubor aktuálních politických či právních požadavků a nároků zpochybňujících samu půdu, na níž stojí poválečné evropské uspořádání“ (Havel in Pithart a Př́hoda 1998: 90-92).

„Je třeba už jednou jasně říct, co všechno patří do historie a s čím vším by se mělo jako s historií nakládat“" (Havel in Pithart a Př́íhoda 1998: 90-92).

Společné prohlášení podepsané sto pěti veřejně, publicisticky a akademicky působícími Čechy a Němci („Prohlášení Smíření 95 mezi Čechy a sudetskými Němci“, in Pithart a Příhoda 1998: 116118). Jejich profesní zázemí podrobně „nastiňuje“ L. Brokl (in Pithart a Příhoda 1998: 131-132).

Zřjmě nejvíce na P. Pitharta, který ovšem zdaleka nebyl iniciátorem a autorem prohlášení a pouze se k němu přihlásil jako jeden ze signatářů.

E. Hahnová to formulovala pregnantně: „Sudetoněmecký problém dnes není otázka, zda, odsunout či neodsunout', nýbrž obraz odsunu v našem historickém vědomí a hledání forem, jak se vyrovnat s jeho následky v české a německé společnosti po padesáti letech“, (in Pithart a Př́hoda 1998: 120-121).

34 Text deklarace je například, poněkud překvapivě, součástí dokumentární př́lohy „Datové příručky - Cesta k dekretům a odsunu Němců“ sestavené J. Němečkem a kol. (2002: 142-145), která zahrnuje i prohlášení „Historikové proti znásilňování dějin - „Stanovisko Sdružení historiků České republiky“، představené 7 . dubna 2002 vedením sdružení (iniciativa J. Pánka a J. Peška), aniž by se členové sdružení k jeho formulaci měli možnost vyjádřit.

Například publicistické příspěvky J. Válka (,Strach z Němců a příprava deklarace“, in Pithart a Př́íhoda 1998: 201-202) či M. Hájka („Deklarace v zájmu českého národa“, in Pithart a Př́ihoda 1998: 212).

3 Těmito jsou ve vztahu k československým Němcům myšleny: „Dekret o neplatnosti některých majetkoprávních jednání z doby nesvobody a o národní správě majetkových hodnot Němců, Mad’arů, zrádců a některých organizací a ústavư“ (č. 5/1945 Sb.), „Dekret o konfiskaci a urychleném rozdělení zemědělského majetku Němců, Mad'arů, jakož i zrádců a nepřátel českého a slovenského národa“ (č. 12/1945 Sb.), „Dekret o úpravě československého státního občanství osob národnosti německé a mad’arské“ (č. 33/1945 Sb.) a „Dekret o konfiskaci nepřátelského majetku a o Fondech národní obnovy“ (č. 108/1945 Sb.)

„Česká strana lituje, že poválečným vyháněním, jakož i nuceným vysídlením sudetských Němců z tehdejšího Československa, vyvlastňováním a odnímáním občanství bylo způsobeno mnoho utrpení a křivd nevinným lidem, a to i s ohledem na kolektivní charakter přisuzování viny“ („Česko-německá deklarace o vzájemných vztazích a jejich budoucím rozvoji“, in Němeček a kol. 2002: 143).

„Zejména lituje excesů, které byly v rozporu s elementárními humanitárními zásadami i s tehdy platnými právními normami, a nadto lituje, že bylo na základě zákona č. 115 z 8 . května 1946 umožněno nepohližet na tyto excesy jako na bezprávné a že následkem toho nebyly tyto činy potrestány“ („Česko-německá deklarace o vzájemných vztazích a jejich budoucím rozvoji“, in Němeček a kol. 2002: 143).

Propracovaněji byl ideový návrat tehdejšího vedení ODS k "německé hrozbě“ v komunistickém stylu vyjádřen v brožuře Benešovy dekrety vydané Centrem pro ekonomiku a politiku (2002), nejexplicitněji Jiřím Weiglem, tehdy řiditelem tohoto sdružení asociovaného s ODS, který spojil problematiku vypořádávání se s odsunem s hrozbou opětné totalitní hegemonie, kterou Německo může nad Evropou nastolit prostřednictvím EU. 
A je-li odhlédnuto od publicisticky laděných a otevřeně tendenčních tiskovin jakou je naprríklad brožura J. Kojzara Byl odsun skutečně nutností?, Futura nakladatelství 2002.

41 Pro přibližení bezprostředně poválečného kontextu publikace zároveň poukazuje (nepříliš konkrétně, s výjimkou konkrétní spekulace o Dánsku) na vystěhovávání menšin, válečných kolonistů a uprchlíků ze středo-západní a západní Evropy bez „velkých formalit a zvláštních legislativních úprav“ (Beneš a kol. 2002: 38).

42 Jejich větší část, navzdory „faktům“ tradovaným za komunistického režimu, odešla do okupačních zón západních spojenců.

43 E. Hahnová popsala pocit jednoho z proslulých německých historiků Hanse Mommsena, účastnícího se na práci komise, jako: „konfrontaci nacionálně indiferentní skupiny německých historiků s nacionálně angažovanými historiky českými, z nichž některé řadí do tradic konzervativní historické vědy, která se upsala snahám o výklad smyslu národních dějin a tvorbě národní identity“ (Respekt, 4/97).

44 Explicitní politický záměr KSČ využít majetku československých Němců k posílení své podpory dokumentují archivní materiály Osídlovací komise při Ústředním výboru KSČ. Například člen KSČ Miroslav Kreysa, přednosta pražské Osídlovací rady, jednoznačně deklaroval, že „musíme tudíž dopodrobna promyslet politické použití tohoto rozdělení majetku, aby nepochybně nový nabyvatelé se museli cítit zavázáni“ (SÚA, f. 23, arch. jedn. 10, interní materiály Osídlovací komise při ÚV KSČ, cit. dle von Arburg 2003: 253-292).

45 M. Kopeček a M. Kunštát přes smírrlivý postoj k textu shledávají hlavní slabinu tohoto „informačního materiálu“ pro učitele ve vyvolání dojmu, „že zde existují dva více-méně přesně oddělitelné diskurzy: jeden ,etizující', který má údajně význam převážně jako zrcadlo doby, v níž ty které texty vznikají, a druhý ,odborný', vedený ,politicky neovlivňovaným historickým výzkumem““ (Kopeček a Kunštát 2003: 311).

Vydaná - jak vyplývá z epilogu a v závěru př́ručky zveřejněného prohlášení Sdružení historiků ČR (ze 7. dubna 2002) - v souvislosti s narůstajícími požadavky zrušení „Benešových dekretư“ ze zahraničí.

47 Práce věnující se odsunu lze rozdělit do dvou velkých skupin. Je zde skupina prací věnující se odsunu z regionálního pohledu (např́íklad Z. Radvanovský: Konec česko-německého soužití v ústecké oblasti 1945-1948, Ústí nad Labem 1997 nebo M. Markel: Vysídlení Němců z Jižní Moravy 1945-1949, Vojenská akademie , Brno 2002), a pak práce věnující se určitému specifickému aspektu odsunu. V souvislosti s nedávnou diskusí o „Benešových dekretech“ se např́íklad objevila řada publikací na toto téma. Často mají spíše ,„pozitivistický“ charakter, což lze pochopit u publikací regionálně-historických, ale u druhé skupiny jde spíše o hledání legality odsunu v detailní právnické deskripci struktury a fungování londýnské a pozdější domácí vlády a právních fines použitých k zabezpečení legality jejich kroků (např́klad J. Kuklík: Mýty a realita takzvaných dekretů. Dekrety prezidenta republiky 1940-1945, Linde, Praha 2002). Je překvapivé, že více než 15 let po roce 1989 je monografických prácí pokoušejících se alespoň o určitou syntézu poznatků na základě předešlého hlubšího výzkumu značně omezené množství (rozhodně mezi ně patří vedle již zmíněných publikací odevírajících téma na začátku 90. let - tedy hlavně monografie T. Staňka [1991] - práce D. Brandese Cesta k vyhnání 1938-1945. Plány a rozhodnutí o „transferu“ Němců z Československa a z Polska, Prostor, Praha 2002).

48 Nový pohled na př́pravu a průběh Postupimské konference, vztahující se k části závěrečného usnesení o odsunu potvrzující klíčovou roli Sovětského svazu v prosazování transferu a výrazně defenzívní pozice USA a Velké Británie, podal M. Churáň (Postupim a Československo: mýtus a skutečnost, Libri, Praha 2001) na základě studia anglických, amerických a sovětských edic zdrojových dokumentů a pramenů a konfrontace se zdroji a prameny české provenience (materiály a dokumenty spojené s činností vlády E. Beneše a paměti jejich aktérů, včetně Benešových). 
Rozsáhle byla diskutována ve středoevropském kontextu např́klad na konferenci On the Histriography of Post-war Europe (1943-1949) zorganizované v rámci výzkumného projektu Legality and Legitimation: Political Justice in the Aftermath of World War II (vedený Tony Judtem z Newyorské univerzity) ve Vídni (IWM) 25.-29. června 1996.

50 Výjimkou z přehledových prací zabývajících se odsunem a poválečnou retribucí po roce 1989 jsou práce T. Staňka (1991, 1996, 2002), poukazující na přítomnost prvků totalitní kontinuity a na proces prosazování elementů komunistického režimu, obvykle spojovaných s přelomem 40. a 50. let, v bezprostředně poválečném období (způsoby vytěžování a využití osob spojených s okupačním režimem proti nekomunistickým politickým aktérům, koordinovaná činnost bezpečnostního a propagandistického aparátu komunisty ovládaných ministerstev apod.).

51 Např́íklad V. Hejl: Zpráva o organizovaném násilí, Univerzum, Praha 1990; K. Kaplan: Pravda o Československu 1945-1948, Praha 1990; K. Kaplan: Nekrvavá revoluce, Mladá fronta, Praha 1993; K. Kaplan: Pět kapitol o únoru, Doplněk, Brno 1997; P. Tigrid: Kapesní průvodce inteligentní ženy po vlastním osudu, Odeon, Praha 1990.

52 K. Langer: Dny strachu, Institut pro středoevropskou kulturu a politiku, Praha 1992; A. Schwarz: Červenobilé křeminky: př́běh Liese 1944-1945, Albis International, Ústí nad Labem 2001; G. Pausewangová: Vzpomínám na Rozinkovou louku, Aurora, Praha 2001; W. Shneiderová: Hořké loučeni s Kopřivnicí. Zážitky mezi útěkem a vyhnáním 1945-1946, Nakladatelství Mecks 2001; H. W. Stolzig: Vic než dva roky života, Albis International, Ústí nad Labem 2003; A. Wágnerová: Odsunuté vzpominky, Prostor, Praha 1993; Svědkové zamlčené minulosti, Svaz Němců v Čechách, na Moravě a ve Slezsku, Praha 1995.

V poslední době se začaly objevovat i vzpomínky na sudetské Němce ze strany jejich českých starousedlých spoluobyvatel, často zahrnující i obrazy násilí nepříliš se lišící od těch, které známe z vyprávění sudetských Němců samotných (viz. J. Škrábek: Včerejši strach, Vyšehrad, Praha 2003; A. Wágnerová: Neodsunuté vzpominky. Česká zkušenost pohraničí, Prostor, Praha 2000).

53 Individuální vyrovnávání se s vyhnáním a návraty do rodné země je působivě popsáno obzvláště G. Pausewangovou v knize Vzpomínám na Rozinkovou louku a H. W. Stolzigem v publikaci Víc než dva roky života.

54 Často jde např́klad o hromadné popravy skupin náhodně vybraných jedinců z osazenstva kárných, internačních a pracovních táborů, v nichž byli koncentrováni práce schopní Němci mužského pohlaví, často pod „formálni““ záminkou útěku jednoho z uvězněných. Svévolné popravy se pochopitelně nevyhýbaly ani ženám, které ovšem rozsáhle podléhaly jiné, specifické formě vražedného a degradujícího násilí.

55 Volkan a Itzkowitz představují tento proces na problematice utváření moderních řeckých a tureckých identit a na „psychodynamice“ řecko-tureckých vztahů. Volkan věnoval pozornost tomuto procesu již v souvislosti s hledáním kořenů nenávisti křest’anských Srbů ve vztahu k bosenským muslimům (1996: 110-127).

56 Podle J. Hartla ze Střediska empirických výzkumů (STEM) dlouhodobé výzkumy změn politických preferencí prokázaly, že anti-německá a nacionalistická profilace předvolební kampaně ODS a nacionalizace dalších mainstreamových stran (ČSSD) v roce 2002 vedla k dlouhodobému posílení KSČM, a to tím, jak byla tato populistická a tradičně marginální agenda legimizována rozsáhlým akcentováním v mainstreamu politického dění (rozhovor s J. Hartlem v rozhlasovém pořadu BBC Omnibus věnovaném problematice nárůstu podpory KSČ, 16. 5. 2004, 11:30).

Muriel Blaive (CeFReS) v populistickém a nacionalistickém využití otázky sudetských Němců v souvislosti s předvolební kampaní v roce 2002 shledala paralelu s ,využitím“ “éto otázky v letech 1945-46, jež nabízí podobné zamyšlení nad charakterem současné demokracie v České republice (2003: 41). 
57 Např́íklad nedávný boj v obou komorách Parlamentu ČR o zákon oceňující zásluhy E. Beneše, navržený především v souvislosti se snahou o zaštítění odsunu, nebo podobné diskuse o oprávněnosti setrvávání prezidenta $\mathrm{V}$. Klauze ve vile zkonfiskované v rámci poválečných represí československých Němců.

58 Zdá se, že tyto reziduální motivy české politiky sehrály výraznou roli i ve volbách do Evropského parlamentu - viz reakce J. Zahradila, lídra kandidátky ODS ve volbách do Evropského parlamentu, který v reakci na iniciativu Evropské lidové strany na zamezení vstupu do Evropského parlamentu bývalým proponentům komunistických režimů z přistupujících východoevropských a středoevropských zemí, poukázal, referujíce k větší otevřenosti KDU-ČSL při diskusích o odsunu sudetských Němců, na nutnost vypořádat se spíše s ,nacistickým“ nebezpečím v řadách KDU-ČSL. Dalším příkladem může být volební kampaň bývalé moderátorky diskusního pořadu Sedmička J. Bobošíkové, která se konkrétně omezila pouze na oblast negativního postoje k sudetským Němcům.

59 O senzitivnosti a problematičnosti spojování a prolínání tematiky represí Židů a Němců viz Hahnová 1999: 265-270.

\section{Literatura}

Abrams, B. F. 1995. „Morality, Wisdom and Revision: The Czech Oppostion of the 1970s and the Expulsion of the Sudeten Germans.“ East European Politics and Societies 9: 234-255.

Arburg, von A. 2003. „Tak či onak: nucené přesídlení v komplexním pojetí poválečné sídelní politiky v českých zemích.“ Soudobé dějiny 3/03: 253-292.

Beneš, Z., Kuklík ml. J., Kural, K., Pešek, 2002. Téma: Odsun-Vertreibung. Transfer Němců z Československa 1945-1947. Praha: SPL - Práce.

Blaive, M. 2003. „O české demokracii a o ,Benešových dekretech““” In M. Blaive, G. Mink (eds.) Benešovy dekrety. Budoucnost Evropy a vyrovnáni se s minulostí. Praha: CeFReS, s. $31-41$.

Brandes, D. 2002. Cesta k vyhnání 1938-1945. Plány a rozhodnutí o „transferu“ Němců z Československa a z Polska. Praha: Prostor.

Brokl, L. 1998. „Dnes se nad čtenářskými ohlasy na téma česko-německých vztahů a výzvy Smíření 95 zamýšlí Lubomír Brokl.“ In P. Pithart, P. Př́ihoda (eds.) Čitanka odsunutých dějin. Praha: Nadace Bernarda Bolzana, Nadace Friedricha Eberta, s. 131-132.

2002. „Česko-německá deklarace o vzájemných vztazích a jejich budoucím rozvoji.“ In J. Němeček a kol. (eds.) Datová př́ručka - Cesta $k$ dekretům a odsunu Němců. Praha: Littera Bohemica, s. 142-145.

Domoslawský, A. 2001. „Kustosz Polski niewinnej.“ Gazeta Wyborcza 190-20. května 2001: 14-16.

Fischl, V. 2003. Žlutý di̊m. Praha: Garamond.

Gross, J. T. 2000. Sasiedzi. Historia zagłady żydowskiego miasteczka. Pogranicze.

Gross, J. T. 2002. „Je lépe být obětí než pronásledovatelem.“ Literární noviny 19/2002: 5.

Hahnová, E. 1999. Sudetoněmecký problém: obtížné loučení s minulostí. Ústí nad Labem: Albis International.

Hahnová, E. 1998. „Sudetoněmecká nedorozumění.“ Lidové noviny 31. 3. 1995. In. P. Pithart, P. Př́ihoda (eds.) Čítanka odsunutých dějin. Praha: Nadace Bernarda Bolzana, Nadace Friedricha Eberta, s. 120-121. 
Hájek, M. 1998. „Deklarace v zájmu českého národa.“ Právo, 27. 12. 1996. In. P. Pithart, P. Př́hoda (eds.) Čítanka odsunutých dějin Praha: Nadace Bernarda Bolzana, Nadace Friedricha Eberta, s. 212.

Havel, V. 1998. „Češi a Němci na cestě k dobrému sousedství.“ In P. Pithart, P. Př́íhoda (eds.) Čítanka odsunutých dějin. Praha: Nadace Bernarda Bolzana, Nadace Friedricha Eberta, s. 90-92.

Hejl, V. 1990. Zpráva o organizovaném násilí. Praha: Univerzum.

Hertl, H. 2001. Němci ven, die deutschen raus! Brněnský pochod smrti 1945. Brno: Dauphin. Churáň, M. 2001. Postupim a Československo: mýtus a skutečnost. Praha: Libri.

Kuklík, J. 2002. Mýty a realita takzvaných dekretio. Dekrety prezidenta republiky 1940-1945. Praha: Linde.

2002. „Historikové proti znásilňování dějin - ,Stanovisko Sdružení historiku České republiky“.“ In J. Němeček a kol. (eds.) Datová přiručka - Cesta k dekretům a odsunu Němců. Praha: Littera Bohemica.

Jarosz, D. , Pasztor M. 1995. W krzywym zwierciadle: Polityka wladz komunistycznych w Polsce $w$ swiatle plotek i poglosek z lat 1949-1956. Varšava: Fakt.

Kaplan, K. 1993. Nekrvavá revoluce. Praha: Mladá fronta.

Kaplan, K. 1997. Pět kapitol o únoru. Brno: Doplněk.

Kaplan, K. 1990. Pravda o Československu 1945-1948. Praha.

Kopeček, M., Kunštát, M. 2003. „,,Sudetoněmecká otázka“ v české akademické debatě po roce 1989.“ Soudobé dějiny 3/03: 293-318.

Langer, K. 1992. Dny strachu. Praha: Institut pro středoevropskou kulturu a politiku.

Mandler, E. 2001. Češi i Němci: legendy, spory, realita. Praha: Libri.

Markel, M. 2002. Vysídlení Němců z Jižní Moravy 1945-1949. Brno: Vojenská akademie.

Mlynárik, J. 1990. „Tézy o vysídlení československých Nemcov.“ In B. Černý, J. Křen , V. Kural, M. Otáhal (eds.) Čě̌i Němci odsun, diskuse nezávislých historiků. Praha: Academia, s. $126-133$.

Mlynárik, J. 1978. „Tézy o vysídlení československých Nemcov.“ Svědectví 57: 105-122.

Pausewangová, G. 2001. Vzpomínám na Rozinkovou louku. Praha: Aurora.

1998. „Prohlášení Smíření 95 mezi Čechy a sudetskými Němci.“ In P. Pithart, P. Př́ihoda (eds.) Čitanka odsunutých dějin. Praha: Nadace Bernarda Bolzana, Nadace Friedricha Eberta, s. 116-118.

Pithart, P., Př́ihoda, P. (eds.) 1998. Čitanka odsunutých dějin. Praha: Nadace Bernarda Bolzana, Nadace Friedricha Eberta

Př́hoda, P. 1998. „Vytěsněné téma se vrací...“. In. P. Pithart, P. Příhoda (eds.) Č́tanka odsunutých dějin. Praha: Nadace Bernarda Bolzana, Nadace Friedricha Eberta, s. 37-53.

Radvanovský, Z. 1997. Konec česko-německého soužití v ústecké oblasti 1945-1948. Ústí nad Labem.

Shneiderová, W. 2001. Hořké loučeni s Kopřivnici; Zážitky mezi útěkem a vyhnáním 1945-1946. Nakladatelství Mecks.

Schwarz, A. 2001. Červenobilé křemínky: přiběh Liese 1944-1945. Ústí nad Labem: Albis International.

Smelser, N. J. „Psychological Trauma and Cultural Trauma.“ In J. Alexander, N. J. Smelser (eds.), Cultural Trauma. California University Press, v tisku. 
Staněk, T. 2002. Retribuční Vězni v českých zemích 1945-1955. Opava: Slezský ústav Slezského zemského muzea.

Staněk, T. 1991. Odsun Němců z Československa 1945-1947. Praha: Academia, Naše vojsko. Staněk, T. 1996. Perzekuce 1945. Praha: Institut pro středoevropskou kulturu a politiku.

Stolzig, H. W. 2003. Víc než dva roky života. Ústí nad Labem: Albis International.

1995. Svědkové zamlčené minulosti. Praha: Svaz Němců v Čechách, na Moravě a ve Slezsku.

Sztompka, P. 2000. „The Other Face of Social Change.“ European Journal of Social Theory 3(4): 449-466.

Škrábek, J. 2003. Včerejši strach. Praha: Vyšehrad.

Tigrid, P. 1990. Kapesní průvodce inteligentní ženy po vlastním osudu. Praha: Odeon.

Uhl, P. 1998. „Sbližování českých a německých nacionalistü“, Právo, 12. 12. 1996. In P. Pithart, P. Př́hoda (eds.) Č́tanka odsunutých dějin. Praha: Nadace Bernarda Bolzana, Nadace Friedricha Eberta, s. 204.

Válka, J. 1998. „,Strach z Němců‘ a příprava deklarace.“ Svobodné slovo, 10. 12. 1996. In P. Pithart, P. Př́hoda (eds.) Čitanka odsunutých dějin. Praha: Nadace Bernarda Bolzana, Nadace Friedricha Eberta, s. 201-202.

Volkan, V. 1996. „Ancient Fuel of a Modern Inferno,“ Mind and Human 1996/3: 110-127.

Volkan, V., D., Itzkowitz, N. 2000. „Modern Greek and Turkish Identities and Psychodynamics of Greek-Turkish Relations. “In A. C. G. M. Robben, M. M. Suárez-Orozco (eds.) Cultures under Siege: Collective Violence and Trauma. Cambridge UK/New York: Cambridge University Press, s. 227-247.

Wágnerová, A. 2000. Neodsunuté vzpomínky. Česká zkušenost pohraničí. Praha: Prostor. Wágnerová, A. 1993. Odsunuté vzpominky. Praha: Prostor.

\section{Autor}

Mgr. Marcel Tomášek působí na Katedře sociologie FSS MU, kde vyučuje kurzy zaměřené na problematiku kolektivního traumatu a násilí, sociální změny a korupce. Vedle zájmu o témata transformace, „state capture“ a evropeizace ve střední Evropě se v Institutu pro reprodukci a integraci společnosti zaměřuje na výzkum tzv. „singles“ a nových forem partnerských vztahů. Kontaktní e-mail: tomasekm@fss.muni.cz 